\title{
Can an Old Dog Learn New Tricks? applying Traditional Corporate law Principles to NEW SOCIAL ENTERPRISE LEGISLATION
}

\author{
Alicia E. Plerhoples*
}

\section{INTRODUCTION}

At the same time that Steve Jobs and Steve Wozniak were building a prototype computer in a garage in Los Altos, California, Ben Cohen and Jerry Greenfield were making ice cream in a gas station in Burlington, Vermont. ${ }^{1}$ Ben \& Jerry's Homemade, Inc. would eventually become an "iconic social enterprise" in the United States. $^{2}$ Despite being organized as a for-profit corporation, Ben \& Jerry's employs a triple bottom line-profits mixed with social and environmental missions. $^{3}$ From 1977 to 2000, Ben \& Jerry's participated in many socially and environmentally beneficial activities. The company purchased ingredients for its ice cream from Vermont dairy farmers, sometimes at a premium to support their

\footnotetext{
* Visiting Assistant Professor, University of California at Hastings College of the Law, spring 2012. Associate Professor of Law, Georgetown University Law Center, starting fall 2012. J.D., Yale Law School; M.P.A., Princeton University. Many thanks to my research assistant Ian Poirier. I would like to thank Rabia Belt, Abraham Cable, G. Marcus Cole, John Crawford, Lisa M. Fairfax, Michael Klausner, Lawrence C. Marshall, David Millon, Jay A. Mitchell, Dana Brakman Reiser, Gail Silverstein, David Takacs, and George Triantis for your helpful discussions and invaluable comments. This article also benefited from comments made by participants at the Center for Law, Economics \& Finance's Junior Business Faculty Roundtable at The George Washington University School of Law, as well as participants at the Junior Faculty Workshop at University of California at Hastings College of the Law.

1 Steve Jobs and Steve Wozniak co-founded Apple in 1976. Apple Incorporated (AAPL) Nens Company Information, NYTiMES.COM, http://topics.nytimes.com/top/news/business/companies/ apple_computer_inc/index.html?scp $=2 \& s q=a p p l e, \% 20$ wozniak,\%201976\&st $=$ cse (last updated Mar. 29, 2012). Ben \& Jerry's Homemade Inc. was founded in 1978. History, BEN \& Jerry's, http://www.benjerry.com/company/history/ (last visited Apr. 8, 2012).

2 Antony Page \& Robert A. Katz, Freezing Out Ben \& Jerry: Corporate Law and the Sale of a Social Enterprise Icon, 35 VT. L. REV. 211, 249 (2010).

3 See Fred Lager, Ben \& Jerry's: The Inside Scoop 222 (1994).
} 
industry; ${ }^{4}$ through its profit-sharing plan, the company disbursed five percent of the company's pretax profits to employees as cash bonuses each year; ${ }^{5}$ the company established the Ben \& Jerry's Foundation and donated seven and one-half percent of its pretax profits to the foundation; ${ }^{6}$ and it partnered with non-profit organizations to open "scoop shops" for the benefit of youths and young adults facing barriers to unemployment. ${ }^{7}$ Many of the Ben \& Jerry's ice cream flavors incorporate ingredients tied to social causes, such as supporting local and sustainable farms, ${ }^{8}$ homelessness prevention, ${ }^{9}$ and rainforest deforestation. ${ }^{10}$ Ben $\&$ Jerry's achieved these social and environmental results while also yielding a profit for its shareholders. ${ }^{11}$

Ben \& Jerry's is a precursor to the growing social enterprise movement. For many social enterprises, how the business operates is just as important as what the business produces. Rather than seek out the cheapest raw materials and labor, many businesses in the social enterprise movement establish their supply chains to source sustainable materials and engage in fair trade practices, while paying fair wages and

${ }^{4}$ Id. at 222. Ben \& Jerry's purchased milk from Vermont dairy farmers at a premium after federal subsidies to the farmers were cut, resulting in a $25 \%$ decline in milk prices. Announcing the decision at a board meeting, Ben Cohen stated that the premium would "come out of "our profits, where it doesn't belong, and into farmers' pockets, where it does belong."”

5 Id. at 129.

${ }^{6}$ Id. at 126.

7 Id. at 244 .

${ }^{8}$ Id. at 222; see also, Page \& Katz, supra note 2, at 220.

9 Page \& Katz, supra note 2, at 221. Chocolate Fudge Brownie was made with brownies baked at the Greyston Bakery, a social enterprise based in Yonkers, New York and dedicated to community renewal by employing homeless and under-employed populations. Id. See also Our Story, GrEYSTON BAKERY, http://www.greystonbakery.com/the-bakery/our-story/ (last visited Apr. 8, 2012).

10 Page \& Katz, supra note 2, at 221. "Rainforest Crunch" was made with Brazil nuts harvested by indigenous populations in the Amazon, providing the population with a source of income. Id. Additionally, 60\% of profits from Rainforest Crunch sales were donated to environmental groups whose mission is preservation of the Amazon rainforest. See Ben and Jerry and Brazil (BEN), AMERICAN UNIVERSITY, http://www1.american.edu/ted/ben.htm (last visited Apr. 8, 2012).

11 Page \& Katz, supra note 2, at 224. Ben \& Jerry's is often criticized for not maximizing profits enough and therefore becoming stagnant and a target for takeover. Id. at 224-26. However, the company's social and environmental efforts were arguably the reason for the company's success, attracting consumers to the product. Id. at 224. 
providing fair benefits to their employees. ${ }^{12}$ This movement has attempted to move beyond corporate social responsibility ${ }^{13}$ or "greenwashing,"-i.e., branding one's company as a "green" business to attract customers but spending nominal money or efforts in actually reducing the company's environmental "footprint." 14 Social enterprises truly "serve two masters" - they have a profit motive, but their social and environmental missions are at the core of their business models. ${ }^{16}$

In the early 1930s, Adolf Berle and E. Merrick Dodd famously debated in the pages of the Harvard Law Review whether a for-profit corporation should combine both social mission and profit motives. Berle argued that "all powers granted to a corporation or to the management of a corporation . . . are necessarily and at all times exercisable only for the ratable benefit of all the shareholders as their interest appears." Responding to Berle, Dodd argued that "there is in fact a growing feeling not only that business has responsibilities to the community but that our corporate managers who control business should voluntarily and without waiting for legal compulsion manage it in such a way as to fulfill those responsibilities." ${ }^{18}$ Dodd

12 See infra notes 63-67 and accompanying text.

13 Corporate social responsibility is seen by some as an attempt by firms to improve their reputations and brands without making sustainable and long-term commitments to producing societal and environmental change. Michael E. Porter \& Mark R. Kramer, Creating Shared Value: How to Reinvent Capitalism — and Unleash a Wave of Innovation and Growth, HARV. Bus. REV. 5 (Jan.-Feb. 2011); see also C. B. Bhattacharya, Corporate Social Responsibility, It's All About Marketing, Forbes.COM (Nov. 20, 2009, 4:15 PM), http://www.forbes.com/2009/11/20/corporate-social-responsibility-leadershipcitizenship-marketing.html.

14 The term "greenwashing" was coined by activist Jay Westerveld in 1986 in response to a hotel's grandiose, if not cynical, claims of being environmentally friendly by washing towels somewhat less frequently than before. See John Sullivan, 'Greenwashing' Gets His Goat: Environmental Activist Coined Famous Term, RECORDOnLINE.COM (Aug. 1, 2009, 2:00 AM), http://www.recordonline.com/apps/ pbcs.dll/article?AID=/20090801/NEWS/908010329/-1/news56.

15 Matthew 6:24.

16 See Porter \& Kramer, supra note 13, at 4 ("Shared value is not social responsibility, philanthropy, or even sustainability, but a new way to achieve economic success. It is not on the margin of what companies do but at the center.’').

17 A. A. Berle, Jr., Corporate Powers as Powers in Trust. 44 Harv. L. REv. 1049, 1049 (1931).

18 E. Merrick Dodd, Jr., For Whom Are Corporate Managers Trustees?, 45 HARV. L. REv. 1145, 1153-54 (1932). 
advanced the notion that the corporation "has a social service as well as a profitmaking function." 19

This article does not take on the broader theoretical debate as to whether corporations should attempt to pursue both economic and non-economic objectives. That debate is the topic of other legal scholarship. ${ }^{20}$ Rather, this article starts from the premise that the social enterprise movement is here and growing, as indicated by the number of states that have adopted new corporate forms to house social enterprise ventures and the number of business schools-both in the United States and in Europe-that are training business leaders and entrepreneurs in the field of social enterprise. ${ }^{21}$

Legislatures are beginning to provide social investors with off-the-shelf corporate forms to employ for social enterprise. In the last two years, two new corporate forms were adopted by or proposed in state legislatures across the United States - the flexible purpose corporation and the benefit corporation. ${ }^{22}$ The benefit

${ }^{19}$ Id. at 1148.

20 See generally Stephen M. Bainbridge, In Defense of the Shareholder Wealth Maximization Norm: A Reply to Professor Green, 50 WASH. \& LEE L. REV. 1423 (1993) (arguing that it is untenable for corporations to refer to both their social mission and shareholder wealth maximization while making business decisions). Contra Ronald M. Green, Shareholders as Stakeholders, Changing Metaphors of Corporate Governance, 50 WASH. \& LEE L. REV. 1409 (1993).

21 See, e.g., Janet E. Kerr, Sustainability Meets Profitability: The Convenient Truth of How the Business Judgment Rule Protects a Board's Decision to Engage in Social Entrepreneurship, 29 CARDOZO L. REv. 623, 629-32 (2007). The law seems to be lagging behind what is occurring in boardrooms and society. Business schools across the country have programs and institutes in social enterprise and are graduating the next generation of corporate executives who believe in creating economic, societal, and environmental value. See John A. Byrne, Social Entrepreneurship: The Best Schools \& Programs, POETS \& QUANTS, http://poetsandquants.com/2010/08/13/social-entrepreneurship-the-best-schools-programs/ (last visited Apr. 8, 2012) (providing the following examples of business schools with prominent programs in social entrepreneurship and social enterprise: Duke University's Fuqua School of Business's Center for the Advancement of Social Entrepreneurship, Stanford Graduate School of Business's Center for Social Innovation, the Skoll Centre for Social Entrepreneurship at Oxford University's Said Business School, Harvard Business School's Social Enterprise Initiative, and Yale University's School of Management's Program on Social Enterprise). Social enterprise is discussed in the Harvard Business Review, the leading business magazine, on a regular basis. See, e.g., Porter \& Kramer, supra note 13, at 4-5.

22 Proponents assert that these corporate forms will hail a new way of doing business. Upon passage of the Benefit Corporation legislation in Maryland (the first state to adopt it), Andrew Kassoy, the cofounder of B Lab, the non-profit organization that drafted the Benefit Corporation legislation is 
corporation was adopted in seven states, including New York and California, and proposed in four others. ${ }^{23}$ The flexible purpose corporation was adopted in California in October 2011 and was introduced into the Indiana legislature in January 2012. ${ }^{24}$ The proliferation of these new corporate forms has been hailed by many as, at least, an innovative step forward in business and, at most, a powerful alternative to corporate greed. ${ }^{25}$ However, a question remains as to how these new corporate forms fit into the existing principles of corporate law and corporate governance. How will traditional corporate law principles be adapted when applied to these new corporate forms? Can an old dog (corporate law) learn new tricks (social enterprise)?

This article begins the project of examining new corporate forms and how traditional corporate law principles might be applied to them. The first endeavor of this project is to examine the fiduciary duty of directors of a flexible purpose corporation under circumstances that would trigger the Revlon rule. ${ }^{26}$ Using Revlon as a proxy allows for examination of the corporate law principles of the "shareholder wealth maximization norm" and "shareholder primacy" and how these norms might inform the fiduciary duties of directors of these new corporate forms. In later

quoted as having said, "For the first time, we have a market-based solution supporting investors and entrepreneurs who want to make money and make a difference." Maryland First State in Union to Pass Benefit Corporation Language, CSRwIRE (Apr. 14, 2010, 10:57 AM), http:/ /www.csrwire.com/ press_releases/29332-Maryland-First-State-in-Union-to-Pass-Benefit-Corporation-Legislation.

Likewise, a petition in favor of the Flexible Purpose Corporation legislation claimed that the "legislation would allow for a new breed of organization where sustainable flourishing of people and the planet could be achieved in one organization." R. Todd Johnson, Help Pass California Legislation that Will Allow Businesses to Do Well and Do Good, CHANGE.ORG, http://www.change.org/petitions/ help-pass-california-legislation-that-will-allow-businesses-to-do-well-and-do-good (last visited Apr. 8, 2012). There is even some suggestion that these new corporate forms should receive preferential legal treatment. Stephanie Strom, A Quest for Hybrid Companies That Profit, but Can Tap Charity., N.Y. TimES, Oct. 13, 2011, at B1.

23 The "benefit corporation" has been adopted in California, Hawaii, Maryland, New Jersey, New York, Vermont, and Virginia. Benefit corporation legislation is pending before the legislatures in Colorado, Illinois, Louisiana, Michigan, North Carolina, Pennsylvania, and Washington, D.C. See State by State Legislative Status, BENEFITCORP.NET, http://www.benefitcorp.net/legislation-demo (last visited Apr. 25, 2012).

24 See The Corporate Flexibility Act of 2011, S.B. 201, 2011 Gen. Reg. Sess. (Cal. 2011); S.B. 62, 117th Gen. Assemb., 2d Reg. Sess. (Ind. 2012).

25 See generally supra note 22.

${ }^{26}$ Revlon, Inc. v. MacAndrews \& Forbes Holdings, Inc., 506 A.2d 173, at 182 (Del. 1986). 
articles, this author intends to examine these and other corporate law principles and their application to social enterprises in different contexts, including other major transactions like initial public offerings and everyday transactions that could lead to "mission-drift."

Beyond examining the fiduciary duties of directors of flexible purpose corporations, the project has two missions: (i) to inform state courts how they might interpret corporate law principles in litigation surrounding these new corporate forms, and (ii) to similarly inform directors, shareholders, and potential investors about how courts might interpret their rights and duties under state corporate law. Until (i) corporate law scholars and practitioners propose how traditional corporate law principles should be applied to social enterprise, and (ii) courts adjudicate issues facing these new corporate forms to create a body of case law, this author predicts that social entrepreneurs and social investors will remain wary of using the new corporate forms for their businesses.

To contribute to this necessary discussion, this article examines the shareholder wealth maximization norm and shareholder primacy through the lens of corporate acquisitions of social enterprises. As the market for products and services produced by social enterprises grows, traditional profit-maximizing corporationswhich may have given limited attention to their social or environmental outputs in the past-will want a piece of this market share and will be able to make a rapid market entrance by acquiring an established social enterprise. ${ }^{27}$ Under certain circumstances, once a social enterprise offers itself for sale, Delaware's Revlon rule would impose heightened judicial scrutiny of the transaction and would require the directors to obtain the best sale price reasonably available, without considering the social enterprise's social and environmental efforts. ${ }^{28}$

The shareholder wealth maximization norm and shareholder primacy are both implicated by the Revlon rule. ${ }^{29}$ However, these two principles are not

27 See infra Part II.B.

28 See Revlon, 506 A.2d at 182.

${ }^{29}$ I do not wish to overstate the significance of Revlon. Subsequent Delaware cases have narrowed the scope of the Revlon rule and some scholars have eschewed its import. Nevertheless, as it stands, the Revlon rule is the most proscriptive use of the shareholder wealth maximization norm in corporate law. And to some extent, corporate managers and their general counsel heed its directive. As such, the Revlon rule presents a useful lens through which to examine the shareholder wealth maximization 
synonymous with the Revlon rule. ${ }^{30}$ Shareholder wealth maximization requires directors to make decisions based solely on the maximization of shareholder value. ${ }^{31}$ Shareholder primacy requires directors to advance and prioritize shareholder interests over non-shareholder interests. ${ }^{32}$ Together, the two principles dictate that when bidders make competing offers for control of the corporation, directors will face heightened judicial scrutiny when a shareholder challenges the proposed or resulting acquisition. ${ }^{33}$ Courts will inquire as to whether directors sought the best value reasonably attainable for the corporation. ${ }^{34}$

This article argues that if the shareholder wealth maximization norm is applied to flexible purpose corporations facing a sale or change in control transaction, it will be applied to the detriment of shareholder primacy. Persons or entities most likely to invest in flexible purpose corporations-namely, impact and social investors-do not want shareholder value prioritized over social and environmental considerations. ${ }^{35}$ The California flexible purpose corporation law explicitly rejects the shareholder wealth maximization norm and allows adoption of charitable purposes or consideration of other constituencies (including the community, society, and the environment) as "special purposes" of the corporation. ${ }^{36}$ Thus, for a flexible purpose corporation, shareholders have both economic and noneconomic interests. ${ }^{37}$

norm and shareholder primacy and how these concepts might be modified to account for the noneconomic interests of shareholders of a flexible purpose corporation.

30 See Revlon, 506 A.2d at 182, 184; see generally ABA Committee on Corporate Laws, Other Constituency Statutes: Potential for Confusion, 45 Bus. LAw. 2253 (1990).

31 See ABA Committee on Corporate Laws, supra note 30, at 2265 ("[T] corporation' are equated with 'corporate profit and shareholder gain.”').

32 See id. at 2565-66.

33 See Revlon, 506 A.2d at 182, 184 (citing the enhanced judicial scrutiny of director conduct in pending take-over bids).

${ }^{34} I d$. at 182.

35 See Susan Moran, Some Ways to Get Started as a Social Entrepreneur, N.Y. TIMES, June 23, 2011, at B5, available at

http://www.nytimes.com/2011/06/23/business/smallbusiness/23sbiz.html?pagewanted=all.

36 CAL. CORP. CODE \2602(b)(2)(B) (Deering 2012).

${ }^{37} I d$. 
Nonetheless, rejecting the shareholder wealth maximization norm creates an accountability gap and possibly gives directors unfettered discretion in their decisionmaking. ${ }^{38}$ To be clear, the California flexible purpose corporation statute does not address how directors and managers of flexible purpose corporations are to account for both the economic and non-economic purposes of the firm. ${ }^{39}$ Moreover, the flexible purpose corporation statute is permissive and does not require directors to take into account the special purposes of the corporation. ${ }^{40}$ Because (i) business decisions of directors are generally protected by the business judgment rule ${ }^{41}$ and (ii) directors are not required to maximize shareholder value or pursue the special purposes of the corporation, directors are unaccountable to shareholders, and shareholder primacy is at risk. ${ }^{42}$ This article discusses and evaluates other potential accountability mechanisms, including a heightened standard of review for directors' decisions affecting the sale or change of control of a flexible purpose corporation.

Part II of this article proceeds with an introduction to social enterprise and its potential to attract large corporate acquirers. Part III presents the shareholder wealth maximization norm and the Revlon rule. Part IV examines the flexible purpose corporation. Part V applies the concept of shareholder primacy to reject the shareholder wealth maximization norm for flexible purpose corporations engaging in a sale or change of control. Part VI considers the gap in directors' accountability left by rejection of the shareholder wealth maximization norm and poses potential solutions to fill the gap, and Part VII offers closing propositions.

\section{THE SOCIAL ENTERPRISE SPECTRUM}

\section{A. Defining Social Enterprise}

Many terms are used to refer to organizations that blend profit motive with social and environmental missions, including "shared value,"43 "social business,"

\footnotetext{
38 See infra Part VI.A.

39 CAL. CORP. CODE \2700(C) (Deering 2012).

${ }^{40} I d$.

41 See, e.g., In re Walt Disney Co. Derivative Litig., 906 A.2d 27, 55, 60 (Del. 2006).

42 See CAL. Corp. Code \2700(C) (Deering 2012).

43 Porter \& Kramer, supra note 13, at 6 (defining "shared value" as "policies and operating practices that enhance the competitiveness of a company while simultaneously advancing the economic and social conditions in the communities in which it operates").
} 
"social entrepreneurship," ${ }^{45}$ "social enterprise,"46 "mission-driven" businesses, ${ }^{47}$ "double bottom line" businesses, ${ }^{48}$ and "triple bottom line" businesses. ${ }^{49}$ Each term varies depending on the person or entity defining the concept, and the mainstream

${ }^{44}$ Muhammad Yunus, the founder and managing director of Grameen Bank uses the term "social business" to describe a business that is either (1) a "non-loss, non-dividend company devoted to solving a social problem and owned by investors who reinvest all profits in expanding and improving the business" or (2) a "profit-making company owned by poor people, either directly or through a trust that is dedicated to a predefined social cause," particularly improving the owners' economic positions. Muhammad Yunus with Karl Weber, Building Social Business: The New Kind of Capitalism that Serves Humanity's Most Pressing Needs 1-2 (2010) [hereinafter Yunus, Building Social Business]. The objective of a social business is to create social benefits for marginalized populations. See id. at 2. A social business aims for "financial and economic sustainability" or "to recover its full costs," distinguishing it from charities, which rely on donations to cover losses. See id. at 3; Muhammad Yunus with Karl Weber, Creating a World Without POVERTY: SOCIAL Business AND THE Future OF CAPiTAlism 22 (2007) [hereinafter Yunus, CREATiNG A WORLD Without POVERTY] (claiming that a social business is not a charity but is a business that must "recover its full costs while achieving its social objectives").

45 Yunus, Building Social Business, supra note 44, at 4 ("'Social entrepreneurship' relates to a person. It describes an initiative of social consequences created by an entrepreneur with a social vision. This initiative may be a non-economic initiative, a charity initiative, or a business initiative with or without personal profit."). According to the Skoll Foundation, one of the leading foundations that funds social entrepreneurship, social entrepreneurs are "[s]ociety's change agents: creators of innovations that disrupt the status quo and transform our world for the better." About, SKOLL FOuND., http://www.skollfoundation.org/about (last visited Apr. 1, 2012). Another leading foundation, the Schwab Foundation for Social Entrepreneurship, states that "[s]ocial entrepreneurship is ... [a]bout applying practical, innovative and sustainable approaches to benefit society in general, with an emphasis on those who are marginalized and poor." What is a Social Entrepreneur?, SCHWAB FOUND. FOR SOCIAL ENTREPRENEURSHIP, http://www.schwabfound.org/sf/SocialEntrepreneurs/ Whatisasocialentrepreneur/index.htm (last visited Apr. 1, 2011).

${ }^{46}$ Rosemary E. Fei, A Guide to Social Enterprise Vebicles, 22 TAX'N OF EXEMPTS 37, 37 (2011) ("In the United States, [social enterprise] broadly encompasses enterprises that seek to achieve their primary social or environmental missions using business methods .... Social enterprise is about change and innovation ....").

47 Marc Lane, Social Enterprise: Empowering Mission-Driven Entrepreneurs 7 (2011) (“" $[\mathrm{S}]$ ocial enterprise' will refer to any business model that, to a significant degree, has a missiondriven motive. This mission-driven motive may be exclusive of a profit motive or blended with one. The mission-driven motive may be primary and the profit motive may be secondary, or vice versa.").

48 Yunus, Building Social Business, supra note 44, at 12.

${ }^{49} \mathrm{Id}$. 
media often uses these terms interchangeably. ${ }^{50}$ However, scholars and practitioners alike distinguish between them. ${ }^{51}$ Theoretically, the organizational spectrum has two extremes. On one end of the spectrum are organizations that pursue social and environmental missions and eschew profit motives, such as non-profit organizations. ${ }^{52}$ On the other end of the spectrum are organizations that focus solely on profit-maximization and disregard social and environmental missions-these might be called profit-maximizing businesses. ${ }^{53}$ Somewhere between these two extremes lie enterprises that blend profit motives and social missions. ${ }^{54}$

To those whose interests lie closer to the end of the spectrum that prioritizes social and environmental values, "social enterprise" means using business techniques to advance socially and environmentally beneficial goals. ${ }^{55}$ According to Social

50 See J. Gregeory Dees, The Meaning of “Social Entrepreneurship," at 1 (May 30, 2001) (unpublished manuscript), available at http://www.caseatduke.org/documents/dees_sedef.pdf ("Many associate social entrepreneurship exclusively with not-for-profit organizations starting for-profit or earnedincome ventures. Others use it to describe anyone who starts a not-for-profit organization. Still others use it to refer to business owners who integrate social responsibility into their operations."); see also Fei, supra note 46, at 37 ("Depending on who is attempting to define the term, varying emphasis may be given, for example, to whether a social enterprise operates for private profit and, if so, to what degree.”). The Social Enterprise Alliance, a non-profit membership association that promotes the work of social enterprises, regards "social entrepreneurship" (as distinct from "social enterprise") as all forms of socially beneficial business activities, including corporate social responsibility. What is Social Enterprise?, SOCIAL ENTER. AlliANCE, https://www.se-alliance.org/what-is-social-enterprise (last visited Mar. 10, 2012) [hereinafter Social Enterprise].

51 See, e.g., Yunus, Building Social Business, supra note 44, at 3-4 ("Terms such as 'social enterprise,' 'social entrepreneurship,' and many others are frequently used in literature devoted to efforts to address problems such as poverty. Although these terms are used in varying ways by different writers, they are generally used to refer to subconcepts within either the profit-making world or the traditional world of non-profit organizations. Thus, they are not the same as what I call social business." (emphasis in original)).

52 See $i d$. at 1 (suggesting that two differing ends of the spectrum include "a traditional profitmaximizing business (which describes practically all private companies in the world today)" and "a not-for-profit organization (which relies on charitable or philanthropic donations)").

53 See id.

54 I speak of mission and motive here, rather than "non-profit" and "for-profit" because a social enterprise can organize as a non-profit public benefit corporation or as a for-profit corporation.

55 See Social Enterprise, supra note 50 (defining "social enterprise" as "an organization or venture that achieves its primary social or environmental mission using business methods"). See also LANE, supra 
Enterprise Alliance, Inc., a non-profit organization that promotes the goals of social enterprise, a social enterprise must "directly address social needs through [its] products and services or through the numbers of disadvantaged people [it] employ[s]." ${ }^{, 56}$ For others, social enterprise means "blended enterprise" or double or triple bottom line businesses-i.e., "entit[ies] that intend] to pursue profits and social good both in tandem and by making considered choices to pursue one over the other." Similarly, "social venture" has been defined as "the combination of mission and venture, in varying degrees.",58

There are also those who promote "shared value" and "blended value"-i.e., "policies and operating practices that enhance the competitiveness of a company while simultaneously advancing the economic and social conditions in the communities in which it operates." ${ }^{29}$ Under the concept of shared value or blended value, there is no choice between profits and social value; both are pursued simultaneously to optimize economic and social value, with social and environmental benefits measured relative to costs. ${ }^{60}$ In advocating a blended value approach, Jed Emerson, founder of one of the first U.S.-based venture philanthropy firms,

note 47 , at 4 (stating that "a social enterprise can be viewed as one not motivated by profit, in that any profit motive takes a back seat to a mission centered on curing an acute social malady").

56 Social Enterprise, supra note 50 (emphasis in original).

57 Dana Brakman Reiser, Blended Enterprise and the Dual Mission Dilemma, 35 VT. L. REV. 105, 105 (2010).

58 Keith B. Artin, Aligning Mission and a Social Venture, in SucceEding AT SOCIAL ENTERPriSE: HardWON LESSONS FOR NONPROFITS AND SOCIAL ENTREPRENEURS 4 (2010); see also Moran, supra note 35 , at B5 ("At a social venture, the social mission is expected to be at least as important as the moneymaking mission.”).

59 Porter \& Kramer, supra note 13, at 6.

${ }^{60} \mathrm{Id}$. at 6-7. This article illustrates the meaning of shared value by contrasting it with the fair trade movement through which farmers are paid premiums for their crops. Id. at 5. Under the principle of shared value, social value is not optimized through payment of premiums because the cost is equal to the benefits and resources are simply redistributed. $I d$. Instead, shared value:

focuses on improving growing techniques and strengthening the local cluster of supporting suppliers and other institutions in order to increase the farmers' efficiency, yields, product quality, and sustainability[,] . . . lead[ing] to a bigger pie of revenue and profits that benefits both farmers and the companies that buy from them.

Id. 
observed that "all organizations, whether for-profit or not, create value that consists of economic, social and environmental value components-and that investors (whether market-rate, charitable or some mix of the two) simultaneously generate all three forms of value through providing capital to organizations." ${ }^{61}$ Because value creation necessarily consists of a blend of social, environmental, and financial values, the blended value approach attempts to maximize the impact of total value rather than any one component that is arguably indivisible from the others. ${ }^{62}$

High profile examples of companies that can be included in the spectrum of social enterprise include TOMS Shoes, Inc.--for every pair of TOMS shoes a customer buys, TOMS donates a pair to a child in a developing country in order to alleviate foot diseases caused by parasites in the soil; ${ }^{63}$ Stonyfield-a yogurt company dedicated to sustainable agricultural practices; ${ }^{64}$ Better World Books—an online

${ }^{61}$ Jed Emerson, About: Blended Value, BlendedVAlue.org, http://www.blendedvalue.org/about/ (last visited Mar. 12, 2012).

${ }^{6}$ See id. ("The outcome of all this activity is value creation and that value is itself non-divisible and, therefore, a blend of [economic, social, and environmental value]." See generally Jed Emerson, Moving Ahead Together, Implications of Blended Value for the Future of Our Work, BLENDEDVALuE.ORG (May 13, 2004), http://www.blendedvalue.org/media/pdf-moving-ahead-together.pdf.

63 One for One, TOMS SHOES, http://www.toms.com/our-movement/movement-one-for-one (last visited Mar. 10, 2012) [hereinafter TOMS SHOES]. TOMS Shoes, Inc. is the brainchild of Blake Mycoskie, who came up with the idea for the shoe company on a vacation to Argentina in 2006. Blake Mycoskie, Start Something That Matters 3, 4-6 (2011). There are at least two other shoe companies that have a one-to-one donation model like TOMS, including Groobs Shoes and TWINS for Peace. Our Crusade, GROOBS, http://www.groobs.com/index.cfm/page/OurCrusade/ our-crusade.cfm (last visted Mar. 10, 2012) (“'B]uying a pair of GROOBS is also giving a new pair of shoes to someone who is homeless in your city and may not own a pair of shoes or a child that has never worn a pair of shoes in their life and has an enormous chance of contracting intestinal worms by not wearing a simple pair of shoes."); Our Philosophy, Twins FOr PEACE, http://www.twinsforpeace.com/philosophie/ (last visited Mar. 10, 2010) (discussing the company's donation of "medical supplies, school tuition, books and supplies to children living in impoverished countries," as well as the one-for-one shoe model).

${ }^{64} \mathrm{Meg}$ Cadoux Hirshberg, The Full Story, STONYFIELD ORGAnIC, http://www.stonyfield.com/aboutus/our-story-nutshell/full-story (last visited Mar. 10, 2012). Started in the late 1970s as a non-profit organization to teach sustainable agricultural practices, Stonyfield is now a for-profit "green" business. It has maintained its dedication to an environmental mission by purchasing its milk from organic family farms, using sustainable packaging, reducing its environmental impact and use of natural resources in production and transportation of its products, and donating $10 \%$ of its profits to environmental causes. Id. 
bookseller that generates funding for non-profit literacy programs by selling books reclaimed from college campuses and libraries; ${ }^{65}$ H.U.M.A.N. Healthy Vending-a company that fights obesity by making healthy food accessible through re-designed vending machines placed in schools and offices, often at little cost to the location provider; ${ }^{66}$ and Greyston Bakery — a Yonkers, New York-based bakery that dedicates itself to community renewal by providing sustainable employment-including fair wages and benefits- to low-income community members and reinvesting all profits in the Greyston Foundation, which provides jobs, job training, affordable housing, youth services, and health care to the Yonkers community. ${ }^{67}$ Each of these social enterprises arguably engages in more than just corporate social responsibility, ${ }^{68}$ cause marketing, or "greenwashing." 69

\section{B. Potential for Acquisitions}

A social enterprise with steady or high growth (or the potential for such) might face a sale or change in control transaction, either because the company's stock price reflects its pursuit of a social or environmental mission or because profitmaximizing businesses want a piece of the market share for conscientious

65 Triple Bottom Line: Social Enterprise, BETTERWORLDBOOKS, http://www.betterworldbooks.com/ info.aspx?f=bottomlines (last visited Mar. 10, 2012). Better World Books—started by two friends who began selling their old textbooks online after they graduated from college-now resells books that would otherwise be thrown away and directs a sizable portion of the books and profits towards literacy initiatives. Id. The company espouses a "triple bottom line," explicitly placing their social and environmental missions on par with their economic objectives. See id.

${ }^{66}$ FAQs: Finances?, HeALTHY VENDING, http://www.healthyvending.com/faqs/locations/vendingmachine-financing (last visited Mar. 28, 2012); The h.u.m.a.n. Mission: Helping Unite Man and Nutrition (h.u.m.a.n.), HeAlthy Vending, http://www.healthyvending.com/aboutus\#2 (last visited Mar. 10, 2012).

${ }^{67}$ Our Story, supra note 9 (Greyston Bakery's motto is, "We don't hire people to bake brownies. We bake brownies to hire people."); Greyston Bakery Becomes the First Benefit Corporation in the State of New York, CSR-WIRE (Feb. 16, 2012, 2:00 PM), http://www.csrwire.com/press_releases/33777-GreystonBakery-Becomes-the-First-Benefit-Corporation-in-the-State-of-New-York ("Greyston Bakery became the first social enterprise to register as a Benefit Corporation in the State of New York.”).

68 See Porter \& Kramer, supra note 13, at 16 (stating that "[corporate social responsibility] programs focus mostly on reputation and have only a limited connection to the business, making them hard to justify and maintain over the long run"); see also Bhattacharya, supra note 13.

69 See Sullivan, supra note 14. 
consumers. $^{70}$ That is, a social enterprise may face a change in control transaction precisely because company earnings are not its only bottom line. ${ }^{71}$ The social enterprise may forgo profits to achieve a social or environmental mission. ${ }^{72}$ For example, TOMS Shoes has given away over one million pairs of shoes. ${ }^{73}$ The management of TOMS Shoes made a strategic decision to start manufacturing operations in Ethiopia and Argentina as part of its social objective to create jobs in the areas where it donates shoes. ${ }^{74}$ Some would argue that choosing to provide jobs where it provides charity rather than ship shoes from China, where it also has manufacturing operations, could come at the expense of company earnings if the labor and raw materials were more cheaply available in China. ${ }^{75}$ The social

70 "Profit-maximizing business," or "PMB," is a term used by Muhammad Yunus to describe companies that seek profits, even if the company also has social or environmental missions. See Yunus, BuILDING SOCIAL Business, supra note 44, at 1.

71 See generally Dennis J. Block, Public Company M\&A: Directors' Fiduciary Duties And Recent Developments In Corporate Transactions, in CONTESTS fOR Corporate CONTROL 2009: Current OfFensive \& DEFENSIVE STRATEGIES IN M\&A TRANSACTIONS (2009).

${ }^{72} I d$.

73 See TOMS SHOES, supra note 63.

74 See TOMS Shoes, SHOE DigeST (July 5, 2011), http://www.shoedigest.com/donate-shoes/tomsshoes.

75 TOMS is privately-held and its financial statements and other corporate information are not publicly available, so it is not clear whether TOMS factories in Ethiopia and Argentina hurt TOMS' financial bottom line. But see KEvin LYNCH \& Julius Walls, JR., Mission Inc.: The Practitioner's Guide to SOCIAL ENTERPRise, 113-15 (2009) (noting that traditional understanding of business costs dictate that:

doing the right thing squeezes your bottom line. Do you want to use environmentally safe, fairly traded, humanely produced raw materials? Your costs of goods will go up. Pay your employees a living wage, provide first class benefits, work reasonable hours? There goes your labor budget. Produce in America, or closely monitor human-rights policies of offshore manufacturers? Too expensive; say good-bye to shelf space at Wal-Mart. Give money to the community to encourage employee volunteerism? Less profit to reinvest in growth. Operate from green, built to last facilities? More up front costs.).

However, Lynch and Walls note that this traditional thinking does not take into account the real costs of business-companies do not bear the full costs of the products they sell when the social and environmental detriments caused by their profit-maximizing activities are externalized and kept off corporate financial statements. 
enterprise's earnings affect its stock price and entice a buyer, either hostile or friendly, in an attempt to achieve greater earnings and higher stock prices for the company. ${ }^{76}$

Many would argue, however, that the financial success of a social enterprise may be because of - and not in spite of - its social and environmental mission, since many consumers prefer socially responsible and environmentally sustainable products and services. ${ }^{77}$ Indeed, it seems more likely that a social enterprise will be targeted by bidders because the target has access to a new and growing market of socially responsible business; profit-maximizing businesses will want to expand into that market by acquiring an established participant rather than starting their own brands. ${ }^{78}$ Such an acquisition leads to an immediate immersion in the market, marked by the legitimacy of the target social enterprise. ${ }^{79}$ Such was the case of Tom's of Maine, Inc. (purchased by Colgate-Palmolive Company), ${ }^{80}$ Burt's Bees, Inc.

\footnotetext{
76 See Block, supra note 71, at 20 (noting that "companies whose stock prices fall may become prime acquisition or leveraged buyout candidates because of their corresponding lack of liquidity and their inability to provide their creative people and senior executives with necessary stock-based incentives").

77 Yunus, Creating a World Without Poverty, supra note 44, at 26.

78 See generally Block, supra note 71.

79 As an example, consider the following statement in Colgate-Palmolive Co.'s 2008 annual report: "Tom's of Maine gave Colgate the opportunity to enter the fast-growing health and specialty trade channel in the U.S. where Tom's of Maine toothpaste and deodorants are market leaders." ColgatePalmolive Co., Annual Report (Form 10-K) (Feb. 28, 2008) [hereinafter Colgate Annual Report]. In a Clorox press release announcing the purchase of Burt's Bees, Clorox's Chairman and CEO Donald R. Knauss announced, "This acquisition allows us to enter a growing market that's consistent with consumer megatrends." Press Release, Clorox Co., Clorox to Acquire Burt's Bees; Expands into Fast-Growing Natural Personal Care (Oct. 31, 2007) (on file with author). Clorox does, however, also have its own brand of natural cleaning products called Green Works. Green Works: our name says it all!, GREEN WORKS, http://www.greenworkscleaners.com/about-us/ (last visited Mar. 28, 2012).

80 See Colgate Annual Report, supra note 79. Tom's of Maine, Inc. was a family-owned company until 2006 when Colgate-Palmolive Company purchased 84\% of its shares for approximately $\$ 100$ million. Id. Our Company: Heritage, TOM's OF MAINE, http://www.tomsofmaine.com/businesspractices/heritage/early-history (last visited Mar. 28, 2012). Tom's of Maine now operates as an independently run division of Colgate. See Colgate Expands Reach of Quirky Toothpaste, USA TODAY (Mar. 21, 2006, 11:47 AM), http://www.usatoday.com/money/industries/retail/2006-03-21-colgatetoms_x.htm. Note that Tom's of Maine, Inc. has no affiliation with TOMS Shoes, Inc.
} 
(purchased by The Clorox Company), ${ }^{81}$ and Ben \& Jerry's (purchased by Unilever). ${ }^{82}$ As one mergers and acquisitions lawyer notes, "it might just be cheaper to buy than build." ${ }^{83}$

Mergers within the same industry can also reduce operating costs by eliminating duplicative employees, plants, and offices, reducing competition within the market. ${ }^{84}$ Once a merger is announced, other companies within the industry are likely to make their own offers in order to remain competitive:

As markets become dominated by fewer and fewer companies, these companies that fail to grow not only may wind up less competitive on a global scale and unprepared to deal with changing technologies or develop new ones, but also may find their strategic options limited if they miss the opportunity to gain a significant market share by merging with a preferred partner. ${ }^{85}$

As more and more social enterprises are established, there is a real possibility that larger, profit-maximizing corporations will target them in order to gain these advantages. How will corporate law principles be applied to handle these acquisitions? What obligation, if any, do the target boards have under traditional corporate law principles to ensure that social enterprises' missions survive?

\section{THE IMPLICATIONS OF THE SHAREHOLDER WEALTH MAXIMIZATION NORM ON SOCIAL ENTERPRISES}

\section{A. Ben \&o Jerry's Revisited}

When directors of a social enterprise start down the path of a change in control transaction or sale, the shareholder wealth maximization norm is implicated. Generally, the shareholder wealth maximization norm stands for the premise that directors' decision-making should be grounded in and directed at maximizing the wealth of the corporation's shareholders, who are the residual claimants on the

81 The Clorox Company purchased 100\% of the stock of Burt's Bees in October 2007 for approximately $\$ 925$ million. The Clorox Company, Current Report (Form 8-K) (Oct. 31, 2007).

82 See generally Ben \& Jerry’s Homemade, Inc., Proxy Statement (Form DEFM 14A) (July 6, 2000).

83 Block, supra note 71, at 20.

${ }^{84}$ Id. at $19-20$.

85 Id. at 20. 
corporation's assets and earnings. ${ }^{86}$ Under Delaware law, the Revlon rule embraces the shareholder wealth maximization norm and shareholder primacy for change in control and sale transactions by requiring directors to focus solely on the firm's intrinsic value to the exclusion of other considerations, such as employees, the environment, and other constituencies (although directors are still given "wide latitude to customize a merger or sales process in the best interests of a target company and its stockholders"). ${ }^{87}$

The sale of Ben \& Jerry's illustrates this issue. In 2000, founders Ben Cohen and Jerry Greenfield, who controlled Ben \& Jerry's board of directors along with director Jeff Furman, allowed Unilever to purchase the corporation, presumably under threat of director liability should they not sell the company to the highest bidder. ${ }^{88}$ Stakeholders and scholars alike lamented the takeover of a mission-driven hometown company by a profit-driven international conglomerate. ${ }^{89}$ Debate surrounds (i) whether Cohen and Greenfield had to sell to Unilever as the highest bidder under the shareholder wealth maximization norm, or (ii) whether Cohen and Greenfield used fiduciary duties as a "scapegoat" to hide their changed priorities and effectively "sold out." As a Vermont corporation, Ben \& Jerry's board of directors

86 See infra Part III.B.

87 See Revlon, Inc. v. MacAndrews \& Forbes Holdings, Inc., 506 A.2d 173, 182 (1986); William Savitt et al., Delaware Court of Chancery Refines Rules for Mixed-Consideration Mergers, THE HARV. L. SCH. F. ON CORP. GOVERnANCE AND FIN. REG. (June 13, 2011, 9:38 AM), http://blogs.law.harvard.edu/ corpgov/2011/06/13/delaware-court-of-chancery-refines-rules-for-mixed-considerationmergers/\#more-18328.

88 Page \& Katz, supra note 2, at 211-12, 228-29 (“[A] person with knowledge of the bidding observed, 'The board felt they had no choice but to let all three groups put their best offers on the table . . . We think it's horrible that a company has no choice but to sell to the highest bidder or get sued.”').

89 See id. at 212, 230. See generally Jenny Kassan, Protecting Your Mission: Legal Tools to Keep Your Company on the Righteous Path, EAST BAY EXPRESS (Feb. 24, 2010), http:/ /www.eastbayexpress.com/

$\mathrm{ebx} /$ protecting-your-mission/Content?oid=1623624.

90 See Page \& Katz, supra note 2, at 226 n.122, 230. Professors Robert A. Katz and Anthony Page vigorously deny that the founders were forced to sell the company; Katz and Page claim that corporate laws concerning takeovers were used by Cohen and Greenfield as a "scapegoat" to hide the fact that their priorities had changed. See id. at 230-31. Katz and Page have attempted to debunk the legal import of the shareholder wealth maximization norm by analyzing case law surrounding the duty of care, the business judgment rule, and constituency statutes. Id. at 231-33, 236. Katz and Page also present a myriad of anti-takeover defenses that the directors of Ben \& Jerry's could have employed to halt the sale of the company to Unilever. Id. at 233-35; see also Kerr, supra note 21, at 634 (arguing that 
was able to consider the interests of non-shareholder constituents-including its employees, creditors, suppliers, the community, and the environment-when it considered bids ${ }^{91}$ because Vermont corporate law contains a constituency statute allowing such considerations. ${ }^{92}$ Indeed, Unilever still continues some, if not all, of

“judicial action and recent shareholder constituency statutes have opened the door to allow directors of public companies to take non-shareholder interests and concerns into consideration when making investment decisions").

91 Ben \& Jerry's Homemade, Inc., Solicitation/Recommendation Statement Under Section 14(d)(4) of the Securities Exchange Act of 1934 (Schedule 14D-9) (Apr. 18, 2000), at 14-15 (referencing the factors that caused the board to approve the sale, including the acquirer's "commitment to sign on, enthusiastically, to pursue and expand the social mission of the Company," the acquirer's commitment to continue to fund the Ben \& Jerry's Foundation, and the effects of the merger on local Vermont communities, suppliers, and franchisees).

92 VT. StAT. ANN. tit. 11A, $\mathbb{} 8.30$ (West 2012). The Vermont legislature amended its business law statute in 1998 to add a constituency statute, partly in anticipation of the Ben \& Jerry's sale. See Page \& Katz, supra note 2, at 236. The pertinent part of the amendment reads:

In determining what the director reasonably believes to be in the best interests of the corporation, a director of a corporation which has a class of voting stock registered under section 12 of the Securities Exchange Act of 1934, as the same may be amended from time to time, may, in addition, consider the interests of the corporation's employees, suppliers, creditors and customers, the economy of the state, region and nation, community and societal considerations, including those of any community in which any offices or facilities of the corporation are located, and any other factors the director in his or her discretion reasonably considers appropriate in determining what he or she reasonably believes to be in the best interests of the corporation, and the long-term and short-term interests of the corporation and its stockholders, and including the possibility that these interests may be best served by the continued independence of the corporation ....

VT. STAT. ANN. tit. 11A, $\int 8.30$ (West 2012) (footnote omitted).

In 2000, during the months surrounding Ben \& Jerry's negotiations with Unilever, the Vermont Office of the Attorney General was asked to issue an Informal Opinion regarding how this amendment changed the standard of conduct for corporate directors. See 2000 VT. ATT'Y. GEN. INFORMAL Op. 2000-2, 2000 WL 34416663, at*1-3. In its opinion, the Office of the Attorney General acknowledged that the Vermont Supreme Court had not addressed the statutory duty of care, "either prior or subsequent to the [constituency statute] amendment," and that "[t]he absence of Vermont law on the subject makes it difficult to determine what effect the amendment has on the obligations of corporate directors." Id. at*1. The opinion looked to relevant cases and American Bar Association commentary on constituency statutes to opine that the statute was likely meant "as a response to, and in effect an abrogation of, the Revlon decision," thereby allowing directors to consider 
Ben \& Jerry's social and environmental missions eleven years after the change in control. $^{93}$ However, some state corporate laws do not contain constituency statutes. ${ }^{94}$ Vermont adopted its own constituency statute shortly before the Ben \& Jerry's acquisition in an attempt to preempt the acquisition and the application of the shareholder wealth maximization norm because of the potential loss of business and jobs in Vermont. ${ }^{95}$

Where a constituency statute is not available and the shareholder wealth maximization norm is applied, risk-averse directors of a social enterprise-fearing liability for a breach of fiduciary duties-may feel obligated to recommend an acquisition by an entity that intends to scale back or even abandon the social or environmental mission of the social enterprise. ${ }^{96}$

\section{B. The Shareholder Wealth Maximization Norm}

Scholars and courts express a director's fiduciary duty to act in the best interest of a corporation as a duty to prioritize the shareholders' interests over interests of other constituencies or to maximize shareholder wealth. ${ }^{97}$ A frequently

the interests of constituents other than shareholders "under all circumstances, including the circumstance in which a decision has been made to sell." Id. at*3.

93 Page and Katz, supra note 2, at 244-45.

${ }^{94}$ Kerr, supra note 21, at 637-38. Constituency statutes were promulgated in many states in the $1980 \mathrm{~s}$ to protect local corporations in response to increased out-of-state takeover activity. See id. Generally, a constituency statute allows directors to consider the interests of non-shareholder constituencies when making business decisions for the corporation. Id. Non-shareholder constituencies include employees, customers, creditors, suppliers, and the communities where the corporation is situated or does business; the national, state, and local economies; both the long-term and short-term interests of shareholders and the corporation; other community and societal factors. Anthony Bisconti, Note, The Double Bottom Line: Can Constituency Statutes Protect Socially Responsible Corporations Stuck in Revlon Land? 42 Loy. L.A. L. REV. 765, 782 (2008). Except for Connecticut's constituency statute, constituency statutes are permissive-directors do not have to consider non-shareholder constituents and factors in their decision-making and non-shareholder constituents do not have a legally enforceable right to enforce their interests. $I d$. at 783 .

95 See supra note 92 and accompanying text.

96 See id.

${ }^{97} \mathrm{ABA}$ Committee on Corporate Laws, supra note 30, at 2265 (stating that "the 'best interests of the corporation' are equated with 'corporate profit and shareholder gain"'). The Model Business Corporation Act codifies the duty of care as a standard of liability for directors, requiring that directors act in good faith, with a reasonable belief that their decisions and actions are in the best 
cited case espousing the shareholder wealth maximization norm is Dodge v. Ford Motor Co., in which the Michigan Supreme Court ordered Henry Ford to pay dividends to Ford shareholders out of significant earnings that Ford had wanted to use for price reductions to benefit the public. ${ }^{98}$ Although the holding of the case was not based on the shareholder wealth maximization norm, the Michigan Supreme Court stated that "[a] business corporation is organized and carried on primarily for the profit of the stockholders. The powers of the directors are to be employed for that end." 99 Similarly, scholars have extolled the virtues of the shareholder wealth maximization norm. In his famous defense of the norm, Milton Friedman posits that directors are employees of the shareholders and, as such, should prioritize their interests:

In a free enterprise, private-property system, a corporate executive is an employe[e] of the owners of the business. He has [a] direct responsibility to his employers. That responsibility is to conduct the business in accordance with their desires, which generally will be to make as much money as possible while conforming to the basic rules of the society .... ${ }^{100}$

Professor Bainbridge has justified the shareholder wealth maximization norm in different terms. ${ }^{101}$ Bainbridge argues that wealth maximization is "the only common denominator" amongst shareholders. ${ }^{102}$ That is, although shareholders may have varied interests (as in the case of socially responsible investors), a significant purpose of investing is to maximize one's own wealth. ${ }^{103}$ Wealth maximization is the

interests of the corporation, and that they remain appropriately informed under the circumstances. MOdel Bus. CORP. ACT \ 8.31(a) (2010).

98 Dodge v. Ford Motor Co., 170 N.W. 668, 683-85 (Mich. 1919).

${ }^{99}$ Id. at 684 .

100 Milton Friedman, A Friedman Doctrine- The Social Responsibility of Business Is to Increase Its Profits, N.Y. Times Magazine, Sept. 13, 1970, at 33.

101 See Bainbridge, In Defense of the Shareholder Wealth Maximization Norm, supra note 20, at 1427-28; see also Stephen M. Bainbridge, The Board of Directors as Nexus of Contracts, 88 IowA L. REV. 1, 6-7 (2002) (arguing that corporate law operates under a "director primacy" norm, whereby directors, and not shareholders, are the decision-makers of the corporation).

102 Bainbridge, In Defense of the Shareholder Wealth Maximization Norm, supra note 20, at 1433 n.35.

103 Id. 
only "common goal" "[i]n a large and diverse shareholder community."104 Bainbridge further argues that the cost of equity capital will rise if directors are allowed to pursue interests other than shareholders' interests. ${ }^{105}$ Allowing directors to take non-shareholder interests into account creates more risk for shareholders, but that risk is not reflected in shareholders' rate of return; shareholders will, therefore, invest stock elsewhere or monitor management more closely, causing the cost of equity to rise. ${ }^{106}$

Although the shareholder wealth maximization norm has been fundamental to the normative constructs of corporate law, there is debate as to whether it accurately describes the current state of corporate law. On one hand, some scholars claim that the shareholder wealth maximization norm is rarely espoused in case law. ${ }^{107}$ These scholars argue that the shareholder wealth maximization norm flies in the face of (i) the business judgment rule, (ii) constituency statutes that allow directors to consider the interests of non-shareholders, and (iii) statutory provisions that protect directors from personal liability to the corporation and its shareholders,

${ }^{104} I d$.

105 Id. at 1433.

106 See id. at 1433. Bainbridge's view (i) fails to acknowledge that social and environmental returns are a measurable, common goal of social investors and (ii) fails to take into account the likelihood that a corporation will face increased costs if it ignores non-economic interests. See Porter \& Kramer, supra note 13, at 5 (acknowledging "social harms or weaknesses frequently create internal costs for firmssuch as wasted energy or raw materials, costly accidents, and the need for remedial training to compensate for inadequacies in education"); Moran, supra note 35, at B5 (quoting Wes Selke, an investment manager at a social-impact venture capital firm, who observed that "more people [are] taking interest in investing in companies that are doing the right thing right from the start"').

107 See Lynn A. Stout, Why We Should Stop Teaching Dodge v. Ford, 3 VA. L. \& Bus. Rev 163, 171 (2008) (confirming that except for Revlon, Inc. v. MacAndrews \& Forbes Holdings, Inc., the Delaware courts have "never actually sanction[ed] directors for failing to maximize shareholder wealth"); see also William T. Allen et al., COMmentaries and CASES On the LaW OF Business Organization 298 (3d ed. 2009) (observing "Dodge . . is one of few decisions by a U.S. court to enforce shareholder primacy as a rule of law. Moreover, it is an old opinion.”); Green, supra note 20 at 1411-12 (stating that generally constituency statutes "represent little more than codifications of the business judgment rule as it has recently been interpreted by the Delaware courts"); Page \& Katz, supra note 2, at 232 (observing that " $[\mathrm{t}]$ he rhetoric of shareholder wealth maximization . . . has produced almost no legal results"). 
such as Delaware Code Annotated section 102(b)(7). ${ }^{108}$ On the other hand, there are those who, like Bainbridge, claim that the norm remains fundamental to positive law:

[T] he mainstream of corporate law remains committed to the principles espoused by the Dodge court. By mainstream I refer of course to Delaware's courts and legislature which are still our premier corporate lawmakers. As it has long done, Delaware law still requires directors to put shareholder interests ahead of those of nonshareholders. At least in Delaware, the shareholder wealth maximization norm thus remains a more accurate description of the state of the law than any of its competitors. ${ }^{109}$

108 See Kerr, supra note 21, at 634 (arguing that "judicial action and recent shareholder constituency statutes have opened the door to allow directors of public companies to take non-shareholder interests and concerns into consideration when making investment decisions"); Page \& Katz, supra note 2, at 232; Stout, supra note 107, at 166, 171 (arguing that Dodge v. Ford is "bad law" because "judges routinely refuse to impose any legal obligation on corporate directors to maximize shareholder wealth").

Professor Lubben and Alana Darnell write about "the waning of the duty of care." Stephen J. Lubben \& Alana Darnell, Delaware's Duty of Care, 31 DeL. J. Corp. L. 589, 589 (2006). Through analysis of Delaware case law, they show that the duty of care "now requires little more of a director than a ritualistic consideration of relevant data. Today, after the director engages in this ritual, her decision will not violate the duty." Id.; see, e.g., Bainbridge, The Board of Directors as Nexus of Contracts, supra note 101, at 6-7 (making the normative argument for the erosion of the duty of care with his theory of "director primacy").

This erosion of the duty of care is due largely to the business judgment rule and Section 102(b)(7)-type charter provisions that exculpate directors from any monetary liability arising from duty of care claims. The business judgment rule stands for the premise that courts will not secondguess good faith decisions made by independent and disinterested directors. See Smith v. Van Gorkom, 488 A.2d 858, 872 (Del. 1985). The courts, therefore, defer greatly to corporate boards in their decision-making so long as a rational process was employed and there are no claims of bad faith or self-dealing (i.e. a breach of the fiduciary duty of loyalty). See In re Caremark Int'l, Inc. Derivative Litig. 698 A.2d 959, 967 (Del. Ch. 1996).

${ }^{109}$ Bainbridge, In Defense of the Shareholder Wealth Maximization Norm, supra note 20, at 1423-25; see also ABA Committee on Corporate Laws, supra note 30, at 2261 (stating its opinion that "the Delaware courts have stated the prevailing corporate common law in this country: directors have fiduciary responsibilities to shareholders which, while allowing directors to give consideration to the interests of others, compel them to find some reasonable relationship to the long-term interests of shareholders when so doing"). 
As this debate continues, it is generally agreed that there is still one area of law where the shareholder wealth maximization norm is clearly implicated-in the context of a sale or change in control transaction. ${ }^{110}$

\section{The Revlon Rule}

In Revlon, Inc. v. MacAndrews \& Forbes Holdings, Inc., the Supreme Court of Delaware affirmed the shareholder wealth maximization norm by holding that during an inevitable sale or dissolution of a company, the directors of the target corporation must allow market forces to "operate freely to bring the target's shareholders the best price available for their equity." 111 Revlon faced a hostile takeover offer from Pantry Pride, Inc. and sought a friendly bidder in Forstmann Little \& Co. ${ }^{112}$ The Revlon board planned several defensive measures to thwart Pantry Pride's tender offers, including the purchase of 10 million shares by Revlon in exchange for senior subordinated notes containing “covenants which limited Revlon's ability to incur additional debt, sell assets, or pay dividends unless otherwise approved by the 'independent' (non-management) members of the board."113 The Revlon board later approved Forstmann's proposal, in part, to protect the noteholders, who had threatened to sue the directors when the value of the notes fell upon announcement that the covenants in the notes would be waived. ${ }^{114}$ The share price of Forstmann and Pantry Pride's offers were relatively similar, but Revlon favored Forstmann, partially because (i) Pantry Pride's chairman and CEO, Ronald Perelman, had a reputation for acquiring companies through junk bond investments and (ii) Pantry Pride intended to break up Revlon and dispose of its assets. ${ }^{115}$ The Delaware

\footnotetext{
110 Revlon, Inc. v. MacAndrews \& Forbes Holdings, Inc. 506 A.2d 173, 182 (Del. 1986) (holding that when Revlon was for sale, ' $[\mathrm{t}$ ] he duty of the board . . . changed from the preservation of Revlon as a corporate entity to the maximization of the company's value at a sale for the stockholders' benefit'); see also Lisa M. Fairfax, Achieving the Double Bottom Line: A Framework for Corporations Seeking to Deliver Profits and Public Services, 9 STAN. J.L. BuS. \& FIN. 199, 219 (stating it is "[o]nly in limited situations where directors contemplate the break-up of the corporation or institute a sale of the corporate enterprise do courts require directors to focus solely on profit maximization”).

111 Revlon, 506 A.2d at 184.

112 Id. at $176-79$.

113 Id. at 177.

114 Id. at $178-79$.

115 Id. at 176-77 (citing Revlon CEO Michael Bergerac's “strong personal antipathy to Mr. Perelman" and Pantry Pride's strategy to acquire Revlon through junk bond financing).
} 
Supreme Court affirmed the Court of Chancery's ruling that "the Revlon directors had breached their duty of loyalty by making concessions to Forstmann, out of concern for their liability to the noteholders, rather than maximizing the sale price of the company for the stockholders' benefit." ${ }^{\text {"116 }}$ The court held:

A board may have regard for various constituencies in discharging its responsibilities, provided there are rationally related benefits accruing to the stockholders. However, such concern for non-stockholder interests is inappropriate when an auction among active bidders is in progress, and the object no longer is to protect or maintain the corporate enterprise but to sell it to the highest bidder. ${ }^{117}$

Notably, the court reasoned that by seeking a friendly bidder and authorizing negotiation of a merger with Forstmann after Pantry Pride's initial hostile tender offer, the Revlon board had put the corporation up for sale. ${ }^{118}$ Once Revlon's sale became inevitable, defensive tactics used to promote bidding and bring shareholders a higher share price were permissible, but the directors' breached their duty of loyalty when employing defensive tactics for the purpose of ending further bidding. ${ }^{119}$ The Revlon rule dictates that, once a company is up for sale, directors cannot favor a particular acquirer over the other while engaged in an active bidding process. ${ }^{120}$ Rather, the "board's primary duty becomes that of an auctioneer responsible for selling the company to the highest bidder."121 Once in Revlon mode, the merger transaction and board's decision-making process face heightened scrutiny when challenged in court. ${ }^{122}$

\footnotetext{
116 Id. at 179.

${ }^{117} I d$. at 182 (citation omitted).

${ }^{118} I d$.

${ }^{119}$ Id. at 183 ("[W] hile those lock-ups which draw bidders into the battle benefit shareholders, similar measures which end an active auction and foreclose further bidding operate to the shareholders' detriment.’).

120 Id. at 184 .

${ }^{121} I d$.

${ }^{122}$ Id. California has yet to consider a case where it might follow Delaware's Revlon rule. California state courts have only cited the Revlon case in two opinions, one published and one unpublished. In 2008, the California Court of Appeals considered application of the Revlon rule in a case involving a breach of fiduciary duty claim because the internal affairs doctrine required application of Delaware
} 
Subsequent Delaware cases made clear that the Revlon rule does not apply to all corporate acquisitions, and, therefore, a target board can attempt to structure its transaction to avoid such duties. For instance, Revlon duties are not triggered in stock-for-stock mergers in which a majority of shares in the surviving entity will be held by a "fluid aggregation of unaffiliated shareholders representing a voting majority" because the target shareholders' control premium will survive the merger. ${ }^{123}$ However, where a shareholder or group of shareholders will hold a controlling block of stock in the resulting entity, Delaware courts have held that Revlon duties are triggered. ${ }^{124}$ In a transcript ruling, the Delaware Chancery Court suggested that the Revlon rule would apply even in a merger where the consideration is a mix of cash and stock and the target stockholders would obtain a control premium in the acquirer. ${ }^{125}$

Very recently, the Delaware Chancery Court extended the Revlon rule to a merger of two publicly-held corporations, where there was no change in control but where the shareholders of the target company received an even mix of cash and stock as consideration for their shares, stating that the transaction deprived the stockholders of their investment's "long-run potential."126 This case seems to have

law, and California law was not implicated. See Greenspan v. Intermix Media, Inc., No. B196434, 2008 Cal. App. LEXIS 8343, at *25, 28 (Cal. Ct. App. Nov. 10, 2008). In Kirscbner Brothers Oil, Inc. v. Natomas Co., the California Court of Appeals cited the Revlon case as authority for the premise that protection of noteholders at the expense of shareholders is inconsistent with a "board's duty to its equity shareholders to maximize the sale price of the company." 229 Cal. Rptr. 899, 907 (Cal. Ct. App. 1986). Nonetheless, the facts of Kirschner did not implicate the Revlon rule per se. The Kirschner court refused to find that fiduciary duty requires directors to preserve the stock value of preferred shareholders because their conversion rights are contractually based, as were the rights of the noteholders in Revlon. Id. at 908.

123 Paramount Commc’ns, Inc. v. Time, Inc., 571 A.2d 1140, 1150-51 (Del. 1989).

124 See Paramount Commc'ns, Inc. v. QVC Network, Inc., 637 A.2d 34, $43-44$ (Del. 1994).

125 See Steinhardt v. Howard-Anderson, No. 5878-VCL, 2012 Del. Ch. LEXIS 1 (Del. Ch. Jan. 6, 2012).

126 See In re Smurfit-Stone Container Corp. S'holder Litig., No. 6164-VCP, 2011 Del. Ch. LEXIS 79, at *45-60 (Del. Ch. May 20, 2011). According to William Savitt:

The Smurfit-Stone decision suggests that deal planners should expect that any merger including a significant amount of cash consideration is likely to be subject to "intermediate" judicial review under Revlon. At the same time, the decision confirms that Delaware continues to afford informed and well-advised independent 
enlarged the circumstances under which the Revlon rule is triggered, although the court acknowledged that the Delaware Supreme Court has not ruled on the issue. ${ }^{127}$ This uncertainty continues to feed into the risk-aversion of directors and corporate managers as they contemplate acquisitions:

A fair statement of current [Delaware takeover] doctrine is that a board sells "control," and thus triggers Revlon duties to seek the highest price and be rigorously fair between competing bidders, when it agrees to exchange a controlling stake in the company, either for cash or non-voting securities, or for voting shares in an acquirer with a controlling shareholder but not when it exchanges $100 \%$ of its voting shares for voting shares in a widely held acquirer, most commonly through a stock-for-stock merger. (Whether Revlon applies to the remaining possibility, exchange of a less than $100 \%$ stake for a widely held acquirer's voting shares, isn't clear.) ${ }^{128}$

When Revlon is triggered is important to the future of many social enterprises, including those social enterprises that incorporate as flexible purpose corporations. One can imagine many scenarios in which the acquisition of a social enterprise, given the fact that it is likely a start-up or early stage company, will trigger Revlon duties. Because a social enterprise is likely to be a small entity (in both size and revenue), any acquisition by a larger profit-maximizing business will not be a "merger of equals" and could therefore result in a diminution of target stockholders' voting power as it is swallowed by the larger entity, of particular concern to Delaware courts. ${ }^{129}$ Or the potential acquirer may cash out all target shareholders and continue operations as a division of the larger corporation (as was the case with Ben \& Jerry's, Burt's Bees,

directors wide latitude to customize a merger or sales process in the best interests of a target company and its stockholders.

Savitt et al., supra note 87.

${ }^{127}$ In re Smurfit-Stone, 2011 Del. Ch. LEXIS 79, at *40.

128 Bernard Black \& Reinier Kraakman, Delaware's Takeover Law: The Uncertain Search for Hidden Value, 96 Nw. U. L. REV. 521, 534-35 (2002); see also Barkan v. Amsted Indus., Inc., 567 A.2d 1279, 1286-87 (Del. 1989) (“[F]airness forbids directors from using defensive mechanisms to thwart an auction or to favor one bidder over another.”).

129 See Paramount Communications Inc. v. QVC Network, Inc., 637 A.2d at 45. 
and Tom's of Maine) or continue the social enterprise's operations in a whollyowned subsidiary of the acquirer. ${ }^{130}$

Professors Bernard Black and Reinier Kraakman have explained the logic of the Revlon line of cases as embracing a hidden value theory-that is, Delaware's takeover jurisprudence embraces the notion that the firm's value is visible and knowable only to its directors and not to shareholders, the stock market, or potential acquirers. ${ }^{131}$ Black and Kraakman explain that, starting with Smith v. Van Gorkom, Delaware takeover jurisprudence asserted the notion that the board of directors must determine the firm's intrinsic value and seek that value for the firm's shareholders in a change of control transaction. ${ }^{132}$ "The board cannot rely on shareholder approval to discharge its duty, nor may it rely principally on prices set by the stock market or the takeover market. Because others may miss the company's hidden value, the board must value the firm itself, preferably with an investment banker's assistance."133 The hidden value theory affirms the Revlon rule's adherence to the shareholder wealth maximization norm such that wealth maximization becomes an exacting standard but also provides well-informed directors with discretion on structuring an acquisition to achieve that value. ${ }^{134}$ According to Black and Kraakman, "language in other cases appears to sanction board consideration of other concerns," but "judicial permission to weigh nonshareholder interests is not a license to ignore shareholder interests; it simply recognizes the broad sweep of the board's discretion to decide what actions will maximize long-run shareholder value."135

130 Mark Cherry, CO-OPs May Have a Homegrown Advantage, HeALTHLEADERS InTERSTUDy (Dec. 16, 2011, 9:45AM), http://hl-isy.com/Healthcare-Reform-Blog/December-2011/co-op-advantage-

121611.

131 Black \& Kraakman, supra note 128, at 521, 559-60 (rejecting the hidden value model in favor of a visible value model with changes in control governed by a bilateral decision-making process, but acknowledging that Delaware courts rely on the hidden value model).

132 Id. at 525-26.

133 Black \& Kraakman, supra note 128, at 526.

134 Id. at 527.

135 Id. at 527-28 (citing Unocal Corp. v. Mesa Petroleum Co., 493 A.2d 946 (Del. 1985) and Paramount Commc'ns, Inc. v. Time, Inc., 571 A.2d 1140 (Del. 1989) for the holdings that a target board may consider constituencies other than shareholders when implementing takeover defenses). The Revlon rule has also been supported by a control premium theory-where a target corporation transfers control to a new controlling shareholder (whether the target corporation previously had a controlling shareholder or not), the target shareholders (other than the controlling shareholder) must 


\section{The Flexible Purpose Corporation}

Responding to the dominance of the shareholder wealth maximization norm and the desire for corporate law to enable businesses along the social enterprise spectrum, corporate law scholars and practitioners worked to rethink the corporate form. The flexible purpose corporation was crafted by the California Working Group for New Corporate Forms, a group of ten corporate lawyers and law professors convened in 2008. ${ }^{136}$ The flexible purpose corporation allows directors and officers to pursue social and environmental objectives along with shareholders' economic interests for those corporations that adopt or convert to the form. ${ }^{137}$

The working group acknowledged the uncertainty of case law surrounding the shareholder wealth maximization norm as to when a director can be held liable for actions taken at the expense of shareholder value. First, the working group argued, the business judgment rule may provide limited protection for directors and officers who attempt to consider all business decisions in light of both the social mission and profit motives of the corporation. ${ }^{138}$ Second, the protection of the business judgment rule is limited with respect to change of control transactions where "boards and management generally have a fiduciary duty to act solely in the interest of maximizing shareholder value."139 Finally, even if the business judgment rule would provide liability protection for specific business decisions based on the

be paid for the sale of those control rights; directors must maximize shareholder value to achieve the control premium for such shareholders. Id. at 535 (citing Paramount Commc'ns, Inc. v. QVC Network, Inc. 637 A.2d 34, 43 (Del. 1994)).

136 See generally W. Derrick Britt et al, Proposed Amendments to the California Corporations Code for a New Corporate Form: The Flexible Purpose Corporation and Senate Bill 201 — Frequently Asked Questions (2011) [hereinafter FPC-FAQ], available at http://businessforgood.blogspot.com/2011/03/frequently-askedquestions-proposed.html.

${ }^{137}$ Id. The flexible purpose corporation was proposed as California Senate Bill 201 ("The Corporate Flexibility Act of 2011") on February 8, 2011 by Senator DeSaulnier. See The Corporate Flexibility Act of 2011, S.B. 201, 2011 Gen. Reg. Sess. (Cal. 2011). The Act was approved by Governor Brown on October 9, 2011 and became effective on January 1, 2012. CAL. CORP. CODE $\ 2500$ (West 2012).

138 See FPC-FAQ, supra note 136, at 5.

${ }^{139} \mathrm{Id}$. 
dual objectives of the corporation, directors remain risk-averse and take conservative positions due to the threat of litigation. ${ }^{140}$ The working group reasoned that:

[b]ecause these rules are judicially created and interpreted, and because litigation is prevalent, even where judicial guidance exists, directors and their lawyers tend to apply risk-averse interpretations, resulting in the practical effect that consideration of "blended value" seldom succeeds in the boardroom if it threatens the maximization of short-term or long-term shareholder profitability. ${ }^{141}$

The flexible purpose corporation is an attempt to break through these barriers posed by the traditional corporation. Specifically, the flexible purpose corporation may adopt "at least one 'Special Purpose' that directors and managers may consider in addition to traditional shareholder economic interests when determining what is in the best interests of the Flexible Purpose Corporation and its shareholders with respect to decisions about operations, policies and transactions."142 These special purposes are:

(A) One or more charitable or public purpose activities that a nonprofit public benefit corporation is authorized to carry out.

(B) The purpose of promoting positive short-term or long-term effects of, or minimizing adverse short-term or long-term effects of, the flexible purpose corporation's activities upon any of the following:

(i) The flexible purpose corporation's employees, suppliers, customers, and creditors.

140 Id.; see also Bisconti, supra note 94, at 793-94 (stating that:

$[\mathrm{T}]$ here is no legal authority protecting a board that rejects a higher value bid out of consideration for nonshareholder interests. Instead, Revlon and its far-reaching precedent provide authority for punishing management for not accepting the higher bid. Since constituency statutes are merely permissive and lack an enforcement mechanism, they do little more than give boards the legislative permission to consider the effects of an acquisition on nonshareholder constituencies. Consequently, a board can disregard these interests without fearing shareholder backlash.).

${ }^{141}$ FPC-FAQ, supra note 136, at 5.

${ }^{142} I d$. at 6. 
(ii) The community and society.

(iii) The environment. ${ }^{143}$

The flexible purpose corporation does not take a redistributive approach. That is, directors of the corporation do not have fiduciary duties to non-shareholders and there is no private right of action against directors by non-shareholder constituents. ${ }^{144}$ Non-shareholder constituents have other means of protecting themselves and expressing their interests-i.e., through contracting with the firm. ${ }^{145}$ By giving only shareholders a private right of action, the flexible purpose corporation statute fully embraces the shareholder primacy norm but acknowledges that shareholders' interests are more than just financial, as will be discussed in Part V. ${ }^{146}$ At the same time, the statement of special purpose in the corporate charter puts the world and investors on notice that both financial and non-economic values will be pursued. $^{147}$

\section{REJECTING WEALTH MAXIMIZATION BUT EMBRACING SHAREHOLDER PRIMACY}

Given the legislative history and purpose of the flexible purpose corporation, it is clear that California courts should not apply a Revlon-type rule to directors of flexible purpose corporations engaging in sale or change of control transactions so far as the Revlon rule requires directors to obtain the best price reasonably attainable at the expense of the special purposes outlined in a flexible purpose corporation's charter. ${ }^{148}$ In addition to the legislative history, my basis for rejecting the shareholder wealth maximization norm but embracing shareholder primacy flows from the nexus of contract theory of corporate law.

\footnotetext{
143 CAL. CORP. CODE \2602(b)(2)(A)-(B) (West 2012).

144 See Bisconti, supra note 94, at 783.

145 See id. at 800 .

146 See infra Part V.

147 The working group designed the flexible purpose corporation with this notice in mind: "Rather, the Special Purpose requirement is designed to put shareholders and potential shareholders on notice that the corporation will pursue agreed interests that may (or may not) align with profit maximization, depending upon the business judgment of the directors, taking into account the Special Purpose." FPC-FAQ, supra note 136, at 7.

148 See Revlon, Inc. v. MacAndrews \& Forbes Holdings, Inc. 506 A.2d 173, 176 (Del. 1986).
} 


\section{A. A New Norm For Impact and Social Investors}

The nexus of contract theory has widespread support amongst corporate law scholars. ${ }^{149}$ Under the nexus of contract theory, "the corporation is properly understood as a legal fiction representing the nexus of a set of contracts among the multiple factors of production provided by the organization's various constituencies." ${ }^{\text {"150 }}$ The corporation brings together the complex and conflicting interests of its constituents, ${ }^{151}$ which include not only its suppliers, employees, creditors, and management, but also its shareholders, as providers of capital. ${ }^{152}$ Just as suppliers and employees enter into supply and employment agreements with the firm, the shareholders' contractual relationship with the firm is set forth in the firm's organizational documents and the corporate laws (common law and statute) of the state of the firm's incorporation. ${ }^{153}$ Shareholders have a residual and contractual

149 See Michael C. Jensen \& William H. Meckling, Theory of the Firm: Managerial Behavior, Agency Costs and Ownership Structure, 3 J. FIN. ECON. 305, 311 (1976) (stating that:

The private corporation or firm is simply one form of legal fiction which serves as a nexus for contracting relationships and which is also characterized by the existence of divisible residual claims on the assets and cash flows of the organization which can generally be sold without permission of the other contracting individuals. Although this definition of the firm has little substantive content, emphasizing the essential contractual nature of firms and other organizations focuses attention on a crucial set of questions - why particular sets of contractual relations arise for various types of organizations, what the consequences of these contractual relations are, and how they are affected by changes exogenous to the organization.).

150 Stephen M. Bainbridge, Unocal at 20: Director Primacy in Corporate Takeovers, 31 DEL. J. CORP. L. 769, 777 (2006); see also Jensen \& Meckling, supra note 149, at 311.

151 Jensen \& Meckling, supra note 149, at 311 (asserting that:

The firm is not an individual. It is a legal fiction which serves as a focus for a complex process in which the conflicting objectives of individuals (some of whom may "represent" other organizations) are brought into equilibrium within a framework of contractual relations. In this sense the "behavior" of the firm is like the behavior of a market, that is, the outcome of a complex equilibrium process.).

152 See Eric W. Orts, Beyond Shareholders: Interpreting Corporate Constituency Statutes, 61 GEO. WASH. L. REV. 14, 21 (1992).

153 Brett W. King, The Use of Supermajority Voting Rules in Corporate America: Majority Rule, Corporate Legitimacy, and Minority Shareholder Protection, 21 DEL. J. CORP. L. 895, 916-17 (1996) (describing the history of corporate law theory and its effects on shareholder voting). 
claim on the corporation's assets. ${ }^{154}$ According to contractarians, the "principal right that flows from the shareholders' status as the corporation's residual claimants" is the shareholder wealth maximization norm. ${ }^{155}$ If the contractarian view of corporate law is to be accepted, then corporate law becomes a default set of rules for the standardized form contract that reduces bargaining costs and facilitates private ordering. ${ }^{156}$ There is "no inherently correct, natural, or logical" rule derived from the nexus of contracts theory other than those that are created from the bargaining amongst the corporation's constituents. ${ }^{157}$ Therefore, that the shareholder wealth maximization norm flows from shareholders' status as the corporation's residual claimants is not an inherent or natural rule but a normative decision resulting from bargaining amongst constituents that can be changed depending on the shareholders' preferences and priorities. ${ }^{158}$

Defenders of the shareholder wealth maximization norm assert that either (i) shareholders do not derive any utility from their investments other than through pecuniary interests or (ii) shareholders' non-pecuniary interests are diverse and immeasurable. ${ }^{159}$ This assertion cannot stand, as applied to the flexible purpose corporation and the type of investor that a flexible purpose corporation is likely to attract-impact investors and social investors. ${ }^{160}$ Although flexible purpose corporations are free to seek and receive capital investment from traditional investors, the flexible purpose corporation is likely to attract impact and social investors, including sustainable and responsible investing funds (which use environmental, social, and governance ("ESG") criteria to vet investment activities), ${ }^{161}$ venture philanthropy firms (which pool funds and distribute them to

\footnotetext{
154 Bainbridge, Unocal at 20, supra note 150, at 777.

155 Id.

156 Bainbridge, In Defense of the Shareholder Wealth Maximization Norm, supra note 20, at 1428; see also King, supra note 153, at 917 (describing corporate law as "enabling legislation ... subject to bargaining and revision by the contracting parties themselves").

${ }^{157}$ King, supra note 153, at 917.

158 See id.

159 See Brian M. McCall, The Corporation as Imperfect Society, 36 DEL. J. CORP. L. 509, 545 (2011).

160 See supra note 35 and accompanying text.

161 According to a report by the US SIF Foundation, $\$ 80.9$ billion was invested by 375 sustainable and responsible investment funds in the beginning of 2011, representing a $15.9 \%$ increase from 2010 . US
} 
social enterprises), ${ }^{162}$ and, depending on the business model, private foundations (which make mission-related investments and socially responsible investments). ${ }^{163}$

Impact investors seek to make investments that create positive impacts and social and environmental benefits beyond financial returns. ${ }^{164}$ The definition of "social investor" varies, but some distinguish social investors from impact investors and limit the term to investors who seek to minimize the negative social and environmental impacts of their investments, as opposed to creating social and environmental benefits. ${ }^{165}$ Others would label social investors as investors who make investment decisions based wholly or in part on non-financial considerations. ${ }^{166}$ This is not to say that impact or social investors wholly subordinate their profit-making

SIF, Study: "Alternative Investment" Assets in Sustainable \& Responsible Investing Jumped 16 Percent in 2010 (Oct. 26, 2011), http://ussif.org/news/releases/pressrelease.cfm?id=181. US SIF Foundation is a non-profit 501(c)(3) organization that supports the research and educational activities of US SIF The Forum for Sustainable and Responsible Investment. See generally US SIF, http://ussif.org (last visited Mar. 15, 2012).

162 LANE, supra note 47, at 188 (stating that:

Venture philanthropy distinguishes itself by:

- $\quad$ its willingness to invest in start-up social enterprises with new approaches to solving social problems;

- $\quad$ its focus on measurable result (i.e., measuring the social impact of a target enterprise);

- $\quad$ its readiness to shift funds between organizations and goals based on the tracking of measurable results; and

- the high involvement of the venture philanthropy firm in the affairs of the target enterprise.).

Lane lists about 50 such venture philanthropy firms. See id.

163 Robert A. Wexler \& David A. Levitt, Using New Hybrid Legal Forms: Three Case Studies, Four Important Questions, and a Bunch of Analysis, 69 ExEMPT OrG. TAX REV. 63, 63 (2012).

${ }^{164}$ For an evaluation of the impact investment market, see generally J.P.MORGAN, Impact Investments: An Emerging Asset Class (Nov. 29, 2010), http://www.jpmorgan.com/cm/BlobServer/ impact_investments_nov2010.pdf?blobkey=id\&blobwhere $=1158611333228 \&$ blobheader=application $\% 2$ Fpdf\&blobcol=urldata\&blobtable=MungoBlobs.

165 See generally Timothy Smith, Institutional Investors Find Common Ground with Social Investors, 1622 P.L.I. CORP. 283 (2007) (discussing various motives of social investors and shareholders).

166 See generally id. 
preferences to the achievement of social and environmental results; many impact and social investors expect to realize financial returns equal to those of traditional investments, although many also expect to make less. ${ }^{167}$ And yet, the expectation that impact or social investments achieve results equal to those of traditional investments should not be confused with the shareholder wealth maximization norm. Impact and social investors' do not always expect the directors and officers to pursue such profits at the expense of social and environmental value creation. ${ }^{168}$

Arguably, the preferences of impact or social investors differ from those of traditional profit-maximizing investors, and, thus, impact and social investors should be able to bargain for a norm that differs from wealth maximization. ${ }^{169}$ How do we know that the flexible purpose corporation incorporates the right set of default rules that impact and social investors would otherwise bargain for on their own? To answer that question, we must look to empirical evidence. The amount of capital flowing into flexible purpose corporations will provide evidence as to whether the flexible purpose corporation statute has chosen the right set of default rules. Because shareholders who invest in a flexible purpose corporation are put on notice that the flexible purpose corporation is fundamentally different than a traditional profit-maximizing corporation, the flexible purpose corporation will attract shareholders who accept this modified contract. ${ }^{170}$ Those shareholders are impact and social investors willing to optimize profits and social and environmental

\footnotetext{
167 Ian B. Lee, Efficiency and Ethics in the Debate About Shareholder Primacy, 31 DEL. J. CorP. L. 533, 558, 573-74 (2006).

168 See generally id.

169 See generally Smith, supra note 165.

170 See CAL. CORP. CODE \2602(b)(2)(A)-(B) (West 2012).
} 
benefits. ${ }^{171}$ Unlike a constituency statute that applies to all corporations in the state where such a statute has been adopted, shareholders have to opt-in to the special purpose of a flexible purpose corporation by either purchasing stock in a flexible purpose corporation or by voting their shares in favor of converting an existing traditional corporation into a flexible purpose corporation. ${ }^{172}$ Measurement of the extent to which investments flow into a flexible purpose corporation will provide evidence that social investors are prepared to displace the shareholder wealth maximization norm and accept a new norm for understanding shareholder value that incorporates social and environmental value. ${ }^{173}$ Notably, we can compare the amount of capital flowing into flexible purpose corporations with the amount of investment in another corporate form that enables social enterprise- the benefit corporation. ${ }^{174}$ Collection of empirical evidence in addition to a comparison with the

${ }^{171}$ In support of the flexible purpose corporation legislation, the Corporations Committee of the State Bar of California recognized the need to accommodate impact and social investors' economic and non-economic interests through new default rules for flexible purpose corporations:

In response to investor demand and the expressed desires of the California Legislature, we support providing consenting business owners a vehicle to structure their business affairs in a novel way to achieve their multiple purposes. We appreciate that some business owners desire their businesses to achieve some higher good, in addition to doing well. We think it is important that California law provide business owners and organizers flexibility to achieve their goals, provided that shareholders are adequately protected by procedural safeguards.

Letter from The Corporations Committee of the Business Law Section of the State Bar of California to The Honorable Juan Vargas, Chair of the Senate Committee on Banking and Financial Institutions (Mar. 25, 2011) (on file with author).

172 See CAL. Corp. CoDE \2602(b)(2)(A)-(B) (West 2012).

173 Nonetheless, the flexible purpose corporation statute became effective January 2012, and I concede that gathering empirical evidence of social investors' investment in this new corporate form will take time as social entrepreneurs begin to incorporate their social ventures as flexible purpose corporations. Moreover, the flexible purpose corporation has only been adopted in one state thus far, whereas the benefit corporation is available in several states-in measuring the capital flow into these forms one would need to control for this fact, possibly by just comparing the capital flow in California which has both the flexible purpose corporation and the benefit corporation.

174 See supra note 23 and accompanying text. Notably, Patagonia, a well-known and privately-held outdoor clothing and gear company, was among the first California corporations to convert to a benefit corporation in January 2012. Patagonia owner and founder Yvon Chouniard cited the ability to maintain Patagonia's environmental mission despite changes in ownership as a reason for Patagonia's conversion. See Marc Lifsher, Businesses Seek State's New Benefit Corporation' Status, L.A. 
benefit corporation will assist scholars and practitioners in understanding the merit of flexible purpose corporations.

\section{B. Measuring the Best Interests of the Corporation}

To the extent that flexible purpose corporation investors have non-economic interests, their interests must be advanced along with the shareholders' financial interests in order to uphold shareholder primacy. ${ }^{175}$ Pursuit of economic interests and the special purpose should define the new meaning of "best interests of the . . corporation" with respect to flexible purpose corporations. ${ }^{176}$ Advancement of the special purpose should be measured and reported the same way that financial returns are-i.e., with accounting methods that monetize and report results relative to costs. ${ }^{177}$ In 2004, the Research Initiative on Social Entrepreneurship ("RISE"), with funding from the Rockefeller Foundation and Columbia Business School, documented and evaluated the effect of social impact accounting on corporations, social ventures, non-profits, foundations, and investors. ${ }^{178}$ RISE found that although no standard measure for social impact accounting yet exists, best practices have emerged. ${ }^{179}$ Two commonly used methods are Social Return on Investment (SROI) and benefit-cost analysis. ${ }^{180}$ RISE aimed its report at institutional social investors

\footnotetext{
Times Jan. 4, 2012), http://www.latimes.com/business/la-fi-benefit-corporations20120104,0,552054.story.

175 See supra note 32 and accompanying text.

176 CAL. Corp. CODE \2700(a) (Deering 2012).

177 See The Roberts Enterprise Development Fund (REDF), SROI Methodology: Analyzing the Value of Social Purpose Enterprise Within a Social Return on INVESTMENT FRAMEWORK 6-7 (2001) [hereinafter REDF], available at http://www.redf.org/learnfrom-redf/publications/119.

178 See generally Catherine Clark et al., Double Bottom Line Project Report: Assessing Social ImpaCt in Double BotTom Line Ventures: Methods CATAlog (2004).

${ }^{179} I d$. at 3.

${ }^{180} I d$. at 32 (stating that:
}

Benefit-cost analysis . . . is a type of economic analysis in which the costs and social impacts of an investment are expressed in monetary terms and then assessed according to one or more of three measures: (1) net present value (the aggregate value of all costs, revenues, and social impacts, discounted to reflect the same accounting periodD]; (2) benefit-cost ratio (the discounted value of revenues and positive impacts divided by discounted value of costs and negative impacts); and (3) 
and social entrepreneurs, helping them "create a set of output indicators that can be tracked relatively easily over time." "181 Likewise, the Sustainability Accounting Standards Board, a U.S.-based non-profit organization, is creating standard social accounting tools in the same manner that the Financial Accounting Standards Board created standards for financial accounting. ${ }^{182}$ As the various methods of assessing social impact continue to develop and firms begin reporting them as they would financial results, investors will be able to demonstrate to boards (with their wallets) the value of common and measurable social and environmental interests. ${ }^{183}$ Moreover, boards may be able to use social impact accounting standards in their evaluations of whether to pursue a sale or change of control transaction. ${ }^{184}$

\section{A GAP IN DiRECTOR ACCOUNTABILITY}

The rejection of the shareholder wealth maximization norm for flexible purpose corporations facing a sale or change of control transaction triggering Revlon duties causes significant problems, the most notable of which is the creation of a gap in directors' accountability to shareholders.

\section{A. The Problem of "Sell-Out" or Mission-Drift}

Assume that courts do not apply the shareholder wealth maximization norm to flexible purpose corporations engaging in a sale or change of control transaction, given (i) rejection of the norm in the flexible purpose corporation statute, ${ }^{185}$ and (ii) adherence to shareholder primacy where shareholders are expected to be social and impact investors with both economic and non-economic motives. ${ }^{186}$ The absence of

internal rate of return (the net value of revenues plus impacts expressed as an annual percentage return on the total costs of the investment[D].).

Social return on investment (SROI) was pioneered by REDF, one of the earliest U.S.-based venture philanthropy firms. For the six-step approach to measuring SROI, see REDF, supra note 177, at 7.

181 CLARK ET AL., supra note 178, at 5.

182 Sustainability ACCT. STANDARDS BD., http://sasb.org/thank-you.html (last visited May 1, 2012).

183 See supra note 173 and accompanying text.

184 See CLARK ET AL., supra note 178, at 3.

185 E.g., Page \& Katz, supra note 2, at 235-36.

186 E.g., Green, supra note 20, at 1410-12. 
the shareholder wealth maximization norm leaves a gap in director accountability to shareholders when engaged in a sale or change of control transaction. ${ }^{187}$ This is because the directors' responsibility to consider the special purpose of the flexible purpose corporation is permissive and not mandatory. ${ }^{188}$ The pertinent part of the statute reads:

In discharging his or her duties, a director may consider . . f factors, and give weight to those factors, as the director deems relevant, including the short-term and long-term prospects of the flexible purpose corporation, the best interests of the flexible purpose corporation and its shareholders, and the purposes of the flexible purpose corporation as set forth in its articles. ${ }^{189}$

While this provision may give directors the necessary discretion to oversee and manage the flexible purpose corporation, it enables the possibility of "sell-out" or mission-drift-i.e., prioritizing shareholder gain at the expense of the social or environmental mission of the firm. ${ }^{190}$ For instance, many claimed that Ben and Jerry's founders Ben Cohen and Jerry Greenfield "sold out" in Unilever's acquisition of Ben and Jerry's. ${ }^{191}$

The statutory language makes clear that directors are free to wholly ignore the special purpose when making decisions, including those decisions involving a sale or change of control. ${ }^{192}$ If a shareholder attempts to bring a derivative suit against directors for failing to consider the special purpose under such circumstances, the court could dismiss the case for failure to state a claim, apply the business judgment rule, or look to the section 102(b)(7) charter provision to exculpate the directors. ${ }^{193}$ The court might also apply the "entire fairness" standard, particularly if the transaction was approved by the shareholders. Under this standard, a director may

\footnotetext{
187 Savitt et al., supra note 87.

188 See CAL. CORP. CODE \2700(c) (Deering 2012).

${ }^{189} I d$. (emphasis added).

190 See Kassan, supra note 89.

191 See Page \& Katz, supra note 2, at 230-31.

192 See CAL. Corp. CoDE \2700(c) (Deering 2012).

193 See supra note 108 and accompanying text.
} 
show that the transaction was "entirely fair" without regard to the special purpose of the flexible purpose corporation. ${ }^{194}$

\section{B. Filling the Gap Through Shareholder Voting Rights \& Contract}

When creating the flexible purpose corporation, the working group recognized the possibility of this subversion of the corporation's special purposes:

[T] he traditional corporate form presents risks for the entrepreneur seeking to maintain the mission of a Special Purpose during the life of an early-stage corporation, without the possibility or probability that investors will shift the company away from the original Special Purpose over time (particularly at the time of a change of control), in favor of additional profitability instead. This difficulty in "anchoring the mission" represents a significant issue for entrepreneurs utilizing a blended value model. ${ }^{195}$

The working group attempted to address the issues of mission-drift and sell-out. First, the flexible purpose corporation statute requires that the corporation maintain transparency by reporting its efforts to achieve the special purpose through an annual report. ${ }^{196}$ Directors must "disclose publicly information regarding objectives, goals, measurement and reporting of the impact or 'returns' of actions vis-à-vis such Flexible Purpose Corporation's Special Purposes." 197 This increased transparency is meant to give shareholders the ability to hold the flexible purpose corporation's directors and officers accountable for their actions to further the flexible purpose corporation's special purpose, just as financial reporting and disclosures act as an accountability tool for financial results. ${ }^{198}$ Presumably, armed with this information, dissatisfied shareholders can attempt to vote out the board or exit the firm themselves by selling their shares. ${ }^{199}$ Both voting and exit are typical corporate

\footnotetext{
194 See, e.g., In re Wheelabrator Techs., Inc. S’holders Litig., 663 A.2d 1194, 1203-04 (Del. Ch. 1995).

195 FPC-FAQ, supra note 136, at 5.

196 Id. at 9.

${ }^{197}$ Id.

198 See id.

199 See id. at 9, 14.
} 
accountability mechanisms. ${ }^{200}$ Nonetheless, shareholder voting as an accountability mechanism is less plausible where a founder or group of early investors controls the board or where the collective action problem exists, and exit becomes problematic when a market for start-up or early-stage company's shares does not exist.

Second, a supermajority (i.e., two-thirds) vote is required to merge with or convert to a traditional corporation or to materially alter the special purpose in the articles of incorporation of a flexible purpose corporation. ${ }^{201}$ Shareholders can simply reject a proposed acquisition that does not further the special purpose of the flexible purpose corporation, or if the controlling shareholder holds two-thirds of the shares, the minority shareholders can rely on dissenters' rights for compensation for their shares. ${ }^{202}$ The supermajority vote requirement, thus, is as strong an accountability mechanism as plausible under the traditional framework of corporate law. $^{203}$

Contractual and market mechanisms also exist to fill the accountability gap and deter mission drift and sell-out. For example, to facilitate the continuance of Ben \& Jerry's social and environmental mission upon Unilever's acquisition, Ben \& Jerry's retained ownership in the company's trademark for ten years post-acquisition and licensed it to Unilever on the condition that Unilever continue Ben \& Jerry's social mission and consult the founders on ways to integrate that mission with the production of Ben \& Jerry's ice cream. ${ }^{204}$

However, the inquiry into directors' accountability should not stop with contractual mechanisms and shareholder voting, despite their obvious utility. To the extent that the flexible purpose corporation is an attempt to provide social investors and entrepreneurs with an off-the-shelf corporate form, default rules could be used to reduce the agency costs associated with deal-specific contractual provisions. ${ }^{205}$

\footnotetext{
200 See, e.g., Harry G. Hutchison, Director Primacy and Corporate Governance: Shareholder Voting Rights Captured by the Accountability/ Authority Paradigm, 36 Loy. U. CHI. L.J. 1111, 1143 (2005).

201 CAL. CORP. CODE SS 3200, 3201 (West 2012).

202 FPC-FAQ, supra note 136, at 14.

203 See id.

204 See supra note 82 and accompanying text.

205 See Jonathan R. Macey \& Geoffrey P. Miller, Reflections on Professional Responsibility in a Regulatory State, 63 GEO. WASH. L. REV. 1105, 1105 (1995).
} 
Moreover, Ben \& Jerry's was a well-established brand that was able to insist on the trademark licensing arrangement. ${ }^{206}$ Other social enterprises may not have the same bargaining power to make such contractual arrangements.

As for supermajority voting, shareholder approval does not discharge directors' fiduciary duties. ${ }^{207}$ Shareholder ratification alters a court's standard of review of the directors' actions, moving from the business judgment rule to an "entire fairness" standard. ${ }^{208}$ Additionally, in an active bidding situation, it is just as likely that the merger proposal will not make it to a shareholder vote without litigation; the bidding parties may seek a preliminary injunction prior to the shareholder vote, and courts will have to interpret the fiduciary duties of the directors of the flexible purpose corporation without regard to shareholder approval (this was the case in Revlon and the subsequent cases that attempted to clarify the Revlon rule). ${ }^{209}$ Therefore, while supermajority shareholder approval and contractual mechanisms certainly mitigate the accountability gap left by rejecting the shareholder wealth maximization norm, accountability through fiduciary duty should still be explored.

\section{Filling the Gap Through Fiduciary Duty}

While directors must be given the necessary deference to exercise their decision-making authority, they must also be held accountable for their actions to advance both the profit motives and special purpose of the flexible purpose corporation in order to avoid sell-out or mission drift. ${ }^{210}$ Shareholder primacy warrants that directors' interests should be aligned with shareholder interests. ${ }^{211}$

206 See History, supra note 1.

207 In re Wheelabrator Techs., Inc. S’holders Litig., 663 A.2d 1194, 1203 (Del. Ch. 1995) (stating that:

In no case has the [Delaware] Supreme Court held that stockholder ratification automatically extinguishes a claim for breach of the directors' duty of loyalty. Rather, the operative effect of shareholder ratification in duty of loyalty cases has been either to change the standard of review to the business judgment rule, with the burden of proof resting upon the plaintiff, or to leave "entire fairness" as the review standard, but shift the burden of proof to the plaintiff.).

${ }^{208}$ Id. at 1205.

209 See Revlon, Inc. v. MacAndrews \& Forbes Holdings, Inc. 506 A.2d 173, 180 (Del. 1986).

210 See supra Part VI.A.

211 See supra Part V. 
Moreover, this author predicts that social investors will not invest in a corporate form that does not protect against the possibility of mission-drift or sell-out.

To fill the gap in director accountability to shareholders of a flexible purpose corporation, a court could point to corporate law's long-established tradition of shareholder primacy, particularly upholding the shareholders' economic and, now, non-economic interests. ${ }^{212}$ In doing so, courts might employ Revlon-like heightened or "intermediate" scrutiny to directors' decisions involving a corporate acquisition, given the ineffectiveness that the business judgment rule would have in protecting shareholders' dual interests. ${ }^{213}$ Under the Revlon analysis, a court will not look solely to the share price to determine whether a board's decision was reasonable. ${ }^{214}$ Instead, the court will use a heightened standard of review that requires additional scrutiny of the board's decision-making process. ${ }^{215}$ The court will ask: Did the directors engage in a decision-making process that indicates they garnered the best value possible for their shareholders ? $^{216}$ Under Revlon, the court will determine (i) whether the board engaged in arms-length decision-making, (ii) whether the merger agreement included coercive deal protections that preclude other potential acquirers, and (iii) what information the board relied on to remain well-informed and welladvised about the acquisition, often including an inquiry into whether the target company engaged in a market check for other potential acquirers or engaged an investment bank to prepare a fairness opinion. ${ }^{217}$

212 See Revlon, Inc., 506 A.2d at 182.

213 See id. at 184.

214 See In re Smurfit-Stone Container Corp. S’holder Litig., No. 6164-VCP, 2011 Del. Ch. LEXIS 79, at *43 (Del. Ch. May 20, 2011) ("When a board leads its corporation into so-called Revlon territory, its subsequent actions will be reviewed by this Court not under the deferential BJR standard, but rather under the heightened standard of reasonableness.").

$215 I d$.

${ }^{216} I d$.

217 See generally Revlon, Inc., 506 A.2d 173. A “market check" is not always required when a transaction enters Revlon mode. Barkan v. Amsted Indus., Inc., 567 A.2d 1279, 1287 (Del. 1989) ("When, however, the directors possess a body of reliable evidence with which to evaluate the fairness of a transaction, they may approve that transaction without conducting an active survey of the market."); see also In re Smurfit-Stone, 2011 Del. Ch. LEXIS 79, at *78 (finding that a market check was not required, even though in Revlon mode, because the merger agreement did not contain preclusive and coercive deal protection terms). 
A similar fiduciary analysis might be used in director liability suits surrounding corporate acquisitions of a flexible purpose corporation. Courts would look at the board's decision-making process and information that it relied upon to remain well-advised and well-informed about the acquisition and the firm's value, which includes the firm's ability to create social and environmental value. A court might inquire whether the social enterprise has engaged in a "market check" or received a fairness opinion that also considers the special purpose of the corporation. This "special purpose check" might require the directors to evaluate not only the target company's value (in both economic and non-economic terms) but also the resulting entity's expected value in non-economic terms using measurements like social return on investment.

There is utility in relying on social accounting metrics even if they are subjective and not yet standardized. Reliance on social impact accounting and measurements is analogous to the fairness opinions that investment bankers provide boards when public companies are sold. ${ }^{218}$ Fairness opinions are not entirely objective. ${ }^{219}$ To a large extent, fairness opinions rest on the many assumptions made by the financial advisor. ${ }^{220}$ Social accounting measurements could be used in the same way that fairness opinions are used to assure that directors are well-informed about the firm's value; social accounting metrics can extend the firm's valuation to social and environmental value creation.

A heightened standard of review is not without its problems. Despite its pomp and circumstance, heightened scrutiny (like the business judgment rule) is still a process-oriented inquiry that would give directors wide discretion in structuring mergers and acquisitions. ${ }^{221}$ Nonetheless, a substantive review of director decisionmaking would be wholly outside the norms of corporate law, for good reason. ${ }^{222}$ Heightened scrutiny may be the only plausible fiduciary analysis that has more teeth than the business judgment rule.

\footnotetext{
218 See Steven M. Davidoff, Fairness Opinions, 55 Am. U. L. REV. 1557, 1558 (2006).

${ }^{219} I d$. at 1576.

220 See id. at 1573-78.

221 See Bainbridge, The Board of Directors as Nexus of Contracts, supra note 101, at 30-31.

222 See generally sources cited supra note 101.
} 


\section{CONCLUSION}

"[S]ocial entrepreneurship is reaching its tipping point.",223 Social enterprise has become (i) the subject of how-to-toolkits for budding entrepreneurs, ${ }^{224}$ (ii) the topic of conferences for investors, entrepreneurs, and consultants around the world, ${ }^{225}$ (iii) the new buzz word in mainstream media, ${ }^{226}$ and (iv) the basis of new programs and institutes at business schools in the U.S. and the United Kingdom. ${ }^{227}$ The traditional view of the corporation as a profit-maximizing villain is overstated, but it has contributed to the current backlash ${ }^{228}$ in the U.S. and elsewhere against corporations as "[c]ompanies are widely perceived to be prospering at the expense of the broader community." 229 An avenue has opened for those shareholders who have both financial and societal interests in mind for their investments-new corporate forms intended to house and advance social enterprises. ${ }^{230}$ And yet, these corporate forms are not viable or sustainable if they do not attract social entrepreneurs or social investors due to the lack of understanding or inquiry into how traditional corporate law principles will be applied to these new corporate forms. ${ }^{231}$ To the extent that directors are risk-averse, the lack of corporate law precedent is a true barrier to the proliferation of these new corporate forms. ${ }^{232}$ This article has

${ }^{223}$ Kerr, supra note 21, at 630.

224 See generally David Bornstein \& Susan Davis, Social Entrepreneurship: What Everyone Needs to Know (2010); J. Gregory DeEs et Al., Enterprising Nonprofits: A Toolkit for SOCIAL ENTREPRENEURS (2001).

225 Consider the SoCap Markets Conference, the Net Impact Conference, and the Social Enterprise Alliance Conference held each year. See NET IMPACT, www.netimpact.org (last visited Mar. 15, 2012); SOCiAl CAPiTAl MARKETS, http://socialcapitalmarkets.net (last visited Mar. 15, 2012); SOCIAL ENTERPRISE ALLIANCE (SEA), www.se-alliance.org (last visited Mar. 15, 2012).

226 See supra notes 43-50 and accompanying text.

227 See supra note 21 and accompanying text.

228 See Occupy Wall Street Inspires Worldwide Protests, NPR.ORG (Oct. 15, 2011), http://www.npr.org/2011/10/15/141382468/occupy-wall-street-inspires-worldwide-protests.

${ }^{229}$ Porter \& Kramer, supra note 13, at 4, 6 (arguing that "rising earnings have done little to offset high unemployment, local business distress, and severe pressures on community services").

230 See supra Part IV.

231 See supra Part III.

232 See supra Part III. 
contributed to a necessary discussion and has begun to map out how the shareholder wealth maximization norm and shareholder primacy might be applied. While I plan to continue this project, I implore others to add their voices to the discussion. 